\title{
1,3,2-Dioxathiolane 2,2-Dioxide as an Electrolyte Additive for K-Metal Cells
}

Tomooki Hosaka, ${ }^{\dagger}$, Taiga Fukabori, ${ }^{\dagger}$ Tatsuo Matsuyama, ${ }^{\dagger}$ Ryoichi Tatara, ${ }^{\dagger, \ddagger}$ Kei Kubota, ${ }^{\dagger, \ddagger}$ and Shinichi Komaba*, ${ }^{*, \neq}$

+ Department of Applied Chemistry Tokyo University of Science Shinjuku, Tokyo 162-8601, Japan.

$\ddagger \quad$ Elements Strategy Initiative for Catalysts and Batteries (ESICB) Kyoto University Goryo-Ohara, Nishikyo-ku, Kyoto 615-8245, Japan

E-mail: komaba@rs.tus.ac.jp 


\section{Experimental Methods}

Electrolyte Preparation: Electrolyte solutions were prepared by mixing potassium bis(fluorosulfonyl)amide (KFSA, $\geq 99.9 \%$, Solvionic) or $\mathrm{KPF}_{6}(\geq 95 \%$, Tokyo Chemical Industry) with battery grade ethylene carbonate (EC):diethyl carbonate (DEC) solvent $\left(1: 1 \mathrm{v} / \mathrm{v}\right.$, Kishida Chemical). $\mathrm{KPF}_{6}$ was dried at $200{ }^{\circ} \mathrm{C}$ for $12 \mathrm{~h}$ under vacuum before the electrolyte preparation. Battery grade electrolyte additives of fluoroethylene carbonate (FEC), difluoroethylene carbonate (DFEC), vinylene carbonate (VC), and ethylene sulfite (ES) were purchased from Kishida Chemical and added by 1 vol\% into $0.8 \mathrm{M} \mathrm{KPF}_{6} / \mathrm{EC}$ :DEC electrolyte. Powder of 1,3,2-dioxathiolane 2,2dioxide (DTD, $\geq 98 \%$, Tokyo Chemical Industry) and trimethylene sulfate (TMS, $\geq 98 \%$, Tokyo Chemical Industry) were added and dissolved by $1 \mathrm{wt} \%$ into $0.8 \mathrm{M} \mathrm{KPF}_{6} / \mathrm{EC}: \mathrm{DEC}$ electrolyte. A series of $0.1 \mathrm{wt} \%$ and 10 wt $\%$ DTD-added electrolytes were also prepared by the same procedure. The K-metal immersion tests were performed by immersing three pieces of K-metal with a diameter of $15 \mathrm{~mm}$ in $1 \mathrm{ml}$ electrolyte solution. Battery grade electrolytes (Kishida Chemical) of $\mathrm{LiPF}_{6} /$ ethylene carbonate (EC):diethyl carbonate (DEC) $(1: 1 \mathrm{v} / \mathrm{v})$ was used for Li cells as received.

Electrode Material and Electrode Preparation: $\mathrm{K}_{2} \mathrm{Mn}\left[\mathrm{Fe}(\mathrm{CN})_{6}\right]$ was synthesized via a chelate-assisted precipitation method as previously reported. The $\mathrm{K}_{2} \mathrm{Mn}\left[\mathrm{Fe}(\mathrm{CN})_{6}\right]$ electrodes consisting of a mixture of $70 \mathrm{wt} \%$ $\mathrm{K}_{2} \mathrm{Mn}\left[\mathrm{Fe}(\mathrm{CN})_{6}\right], 20 \mathrm{wt} \%$ Ketjen black (KB, Carbon ECP, Lion), and $10 \mathrm{wt} \%$ poly(vinylidene fluoride) (PVdF, \#9100, Kureha) were prepared, and graphite electrodes were prepared by mixing $89 \mathrm{wt} \%$ artificial graphite, $6 \mathrm{wt} \%$ acetylene black (AB, Li400, Denka), and 5 wt\% sodium carboxymethyl cellulose (CMC, \#2200, Daicel FineChem). Both electrodes were prepared by coating mixture slurry on $\mathrm{Al}$ foil and drying the coat at $150{ }^{\circ} \mathrm{C}$ under vacuum. Activated carbon electrodes consisting of $80 \mathrm{wt} \%$ activated carbon (YP50F, Kuraray), $10 \mathrm{wt} \% \mathrm{~KB}$, and $10 \mathrm{wt} \%$ polytetrafluoroethylene (PTFE, Daikin) were formed on $\mathrm{Al}$ expanded metal and dried at $200{ }^{\circ} \mathrm{C}$ under vacuum. Liand K-metal electrodes were prepared from Li foil (Honjo Chemical) and K chunk (Sigma-Aldrich). K metal was cut properly and rolled to fix a thickness of approximately $1 \mathrm{~mm}$ using a metal roller before punching into circular electrodes with a diameter of $10 \mathrm{~mm}$.

Electrochemical and Electrode Characterization: Linear sweep voltammetry were conducted with a threeelectrode cell (SB1A, EC FRONTIER) with Al foil as a working electrode, the activated carbon counter electrode, and a $\mathrm{K}$ metal (Sigma-Aldrich) reference electrode. Galvanostatic charge-discharge tests of $\mathrm{K}_{2} \mathrm{Mn}\left[\mathrm{Fe}(\mathrm{CN})_{6}\right]$ electrodes were conducted with 2032 coin-type cells in which a $\mathrm{K}$ metal counter electrode and a glass fiber separator (GB-100R, Advantec) were used. Al-clad cathode caps (Hohsen) were used for the coin-type cells to avoid the effect of stainless-steel corrosion. For K-metal symmetric cells, two stacked filters were placed in between of $\mathrm{K}$ electrodes to avoid short-circuit. These cells were fabricated in the Ar-filled glovebox where the dew point is lower than $-80^{\circ} \mathrm{C}$. Some cells specially mentioned were fabricated in the glovebox equipped with a cold trap (UT2000, EYELA) to remove organic solvent vapor. The plating/stripping tests for the $\mathrm{Li}\|\mathrm{Li}, \mathrm{Na}\| \mathrm{Na}, \mathrm{K} \| \mathrm{K}$, and $\mathrm{K} \| \mathrm{Cu}$ cells were conducted at a current density of $25 \mu \mathrm{A} \mathrm{cm}^{-2}$ at $25^{\circ} \mathrm{C}$. Each plating/stripping duration was fixed to be $10 \mathrm{~h}$. Upper voltage limit was set to $2.0 \mathrm{~V}$ for the $\mathrm{K} \| \mathrm{Cu}$ cell. Electrochemical impedance spectroscopy was carried out in a frequency range from $100 \mathrm{kHz}$ to $10 \mathrm{mHz}$ with an alternating current signal amplitude of $10 \mathrm{mV}$ using VMP3 (Biologic). Galvanostatic charge/discharge tests of the graphite electrode were conducted in a threeelectrode cell (TYS-00DM02D, Toyo system) at the potential range of $0.05-2.00 \mathrm{~V}$ and a current density of 27.2 $\mathrm{mA} \mathrm{g} \mathrm{g}^{-1}$ corresponding to $\mathrm{C} / 10$. During the potassiation process, constant voltage at $0.05 \mathrm{~V}$ for $3 \mathrm{~h}$ was applied after the galvanostatic potassiation. Before the charge/discharge tests, a K-metal counter electrode (CE) and a reference electrode (RE) were pretreated by plating/stripping for two cycles, ensuring the absolute potential difference of CE and RE was less than $2 \mathrm{mV}$. Fourier transform infrared (FTIR) spectroscopy measurements by attenuated total reflection (ATR) method were conducted using Alpha II (Bruker) inside the glovebox to avoid air exposure of the samples.

Gas chromatography-mass spectrometry (GC-MS): The GC-MS measurements were conducted with a GCMS-QP2020 NX (Shimadzu). A mid-polar SH-Rtx-200 $(30 \mathrm{~m} \times 0.25 \mathrm{~mm} \times 0.25 \mu \mathrm{m})$ column was used. He gas (G1 grade, $>99.99995$ vol.\%) was used as carrier gas with $48 \mathrm{~cm} \mathrm{~s}^{-1}$ linear velocity. The temperature program started at $40{ }^{\circ} \mathrm{C}$ which was held for $2 \mathrm{~min}$. Afterwards, temperature ramps with $7{ }^{\circ} \mathrm{C} \mathrm{min}{ }^{-1}$ until $100{ }^{\circ} \mathrm{C}$ and $12{ }^{\circ} \mathrm{C}$ $\mathrm{min}^{-1}$ until $280{ }^{\circ} \mathrm{C}$ followed. The final temperature was held for $5 \mathrm{~min}$. The mass range was $20-600 \mathrm{~m} / \mathrm{z}$ and an event time of $0.3 \mathrm{~s}$ in scan mode. Ionization was performed by electron ionization (EI) or chemical ionization (CI) using isobutane gas (>99.9\%). 


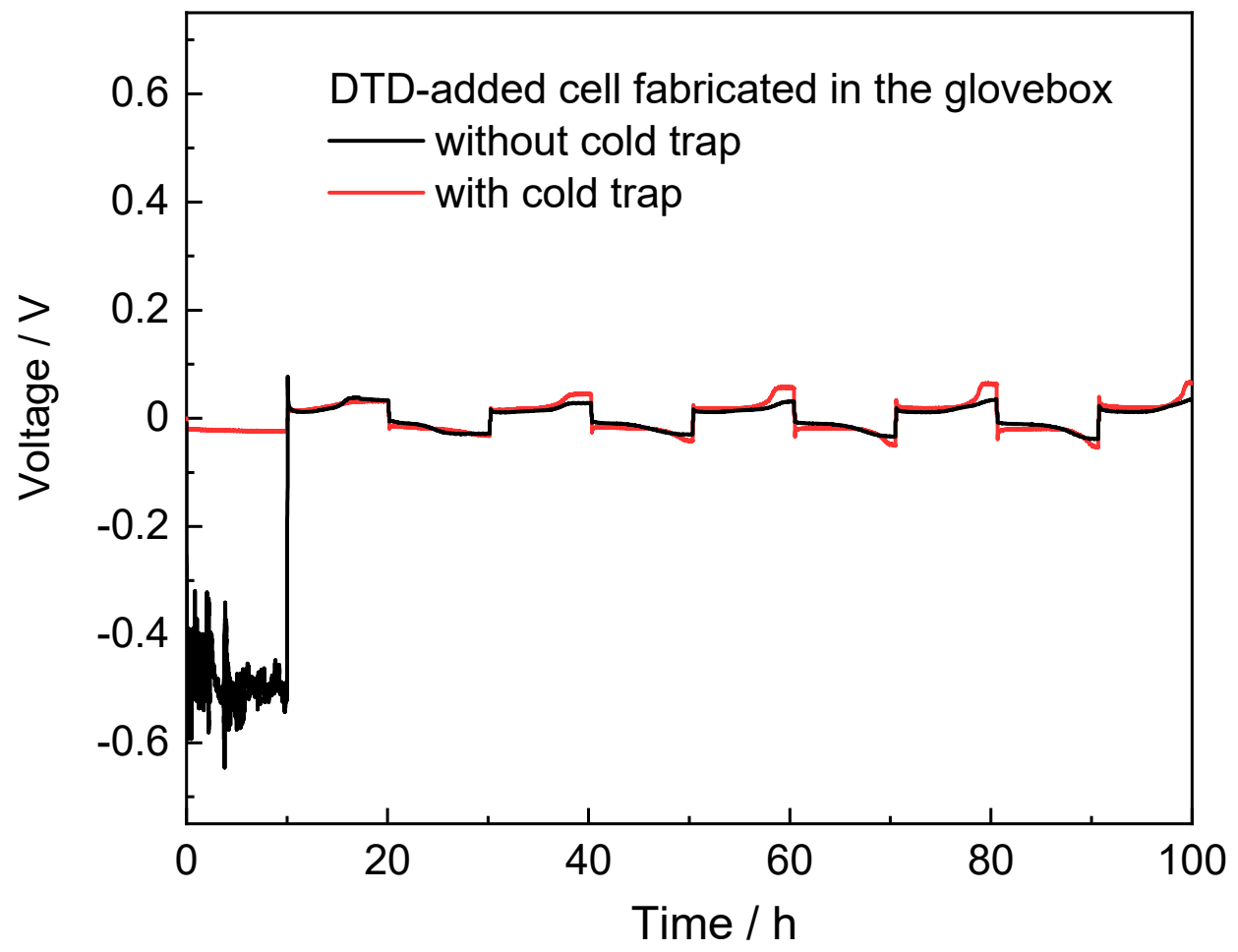

Figure S1. Voltage profiles of repeated K plating-stripping in $\mathrm{K}|| \mathrm{K}$ cells filled with 0.8 $\mathrm{M} \mathrm{KPF}_{6} / \mathrm{EC}: \mathrm{DEC}$ with $1 \mathrm{wt} \%$ of DTD fabricated in the glovebox with or without cold trap. 

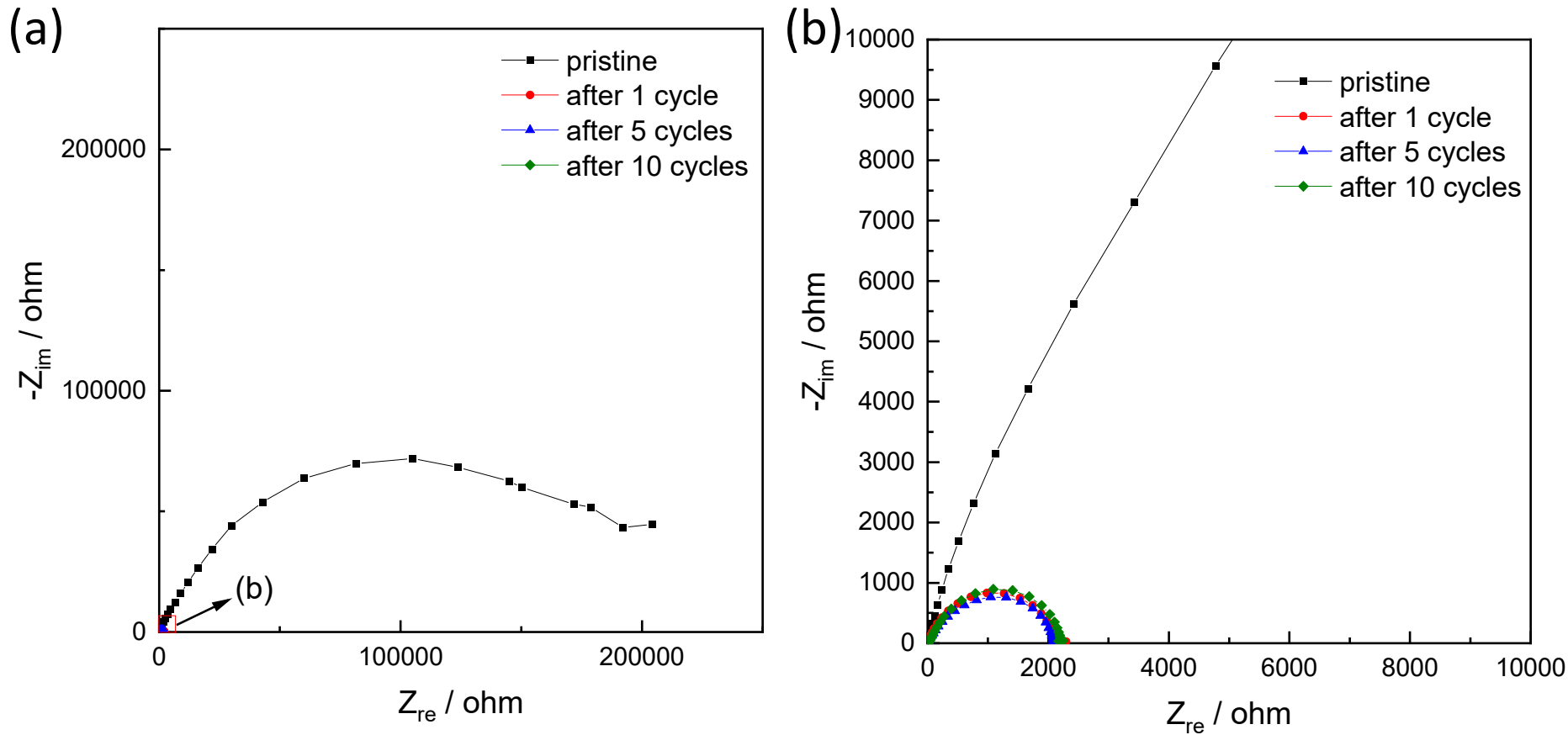

Figure S2. (a) Nyquist plots of $\mathrm{K} \| \mathrm{K}$ coin cells filled with $0.8 \mathrm{M} \mathrm{KPF}_{6} / \mathrm{EC}: \mathrm{DEC}+1 \mathrm{wt} \%$ DTD and (b) its enlarged figure. 


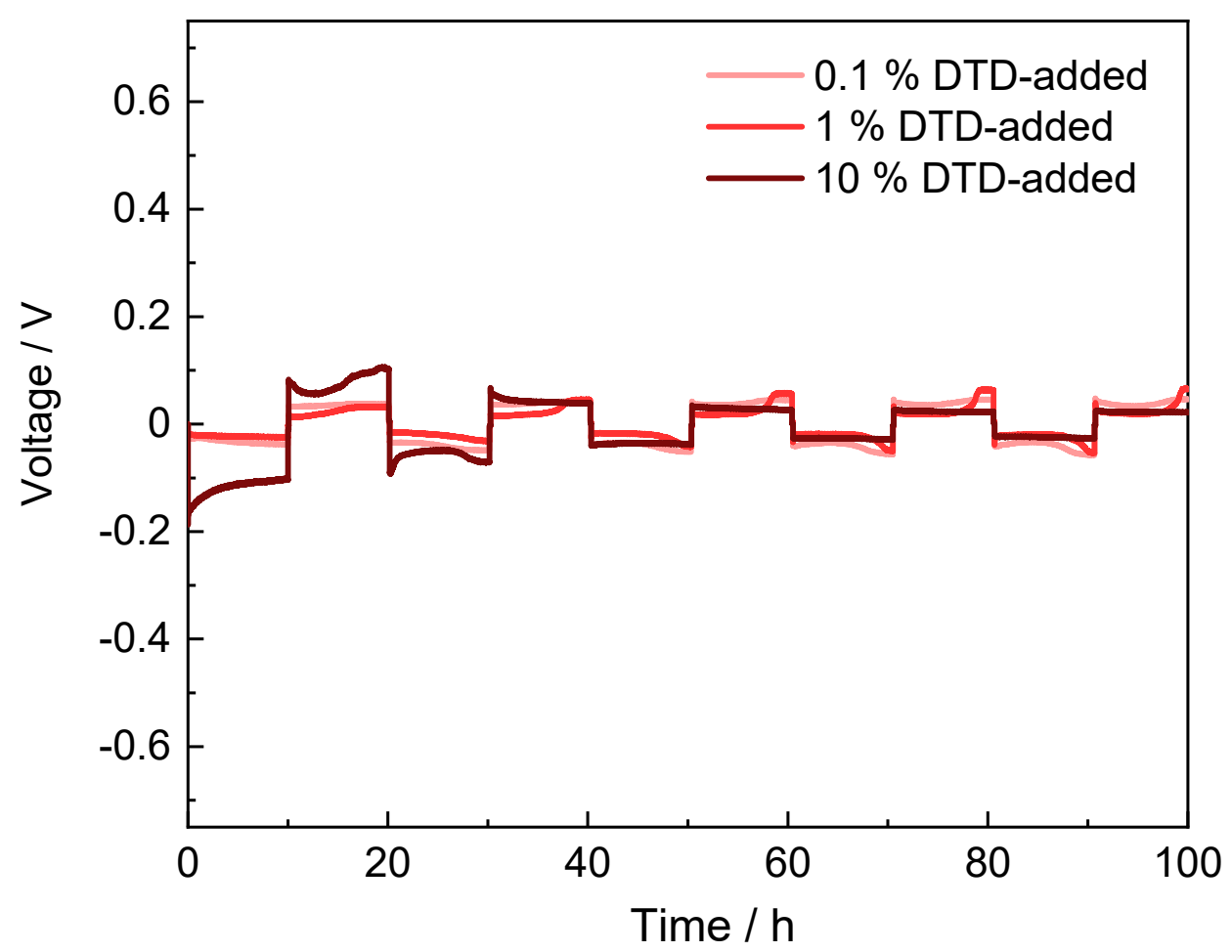

Figure S3. Voltage profiles of $\mathrm{K} \| \mathrm{K}$ cells filled with $0.8 \mathrm{M} \mathrm{KPF}_{6} / \mathrm{EC}: \mathrm{DEC}$ with $0.1,1$, and $10 \mathrm{wt} \%$ of DTD fabricated in the glovebox with cold trap. . 


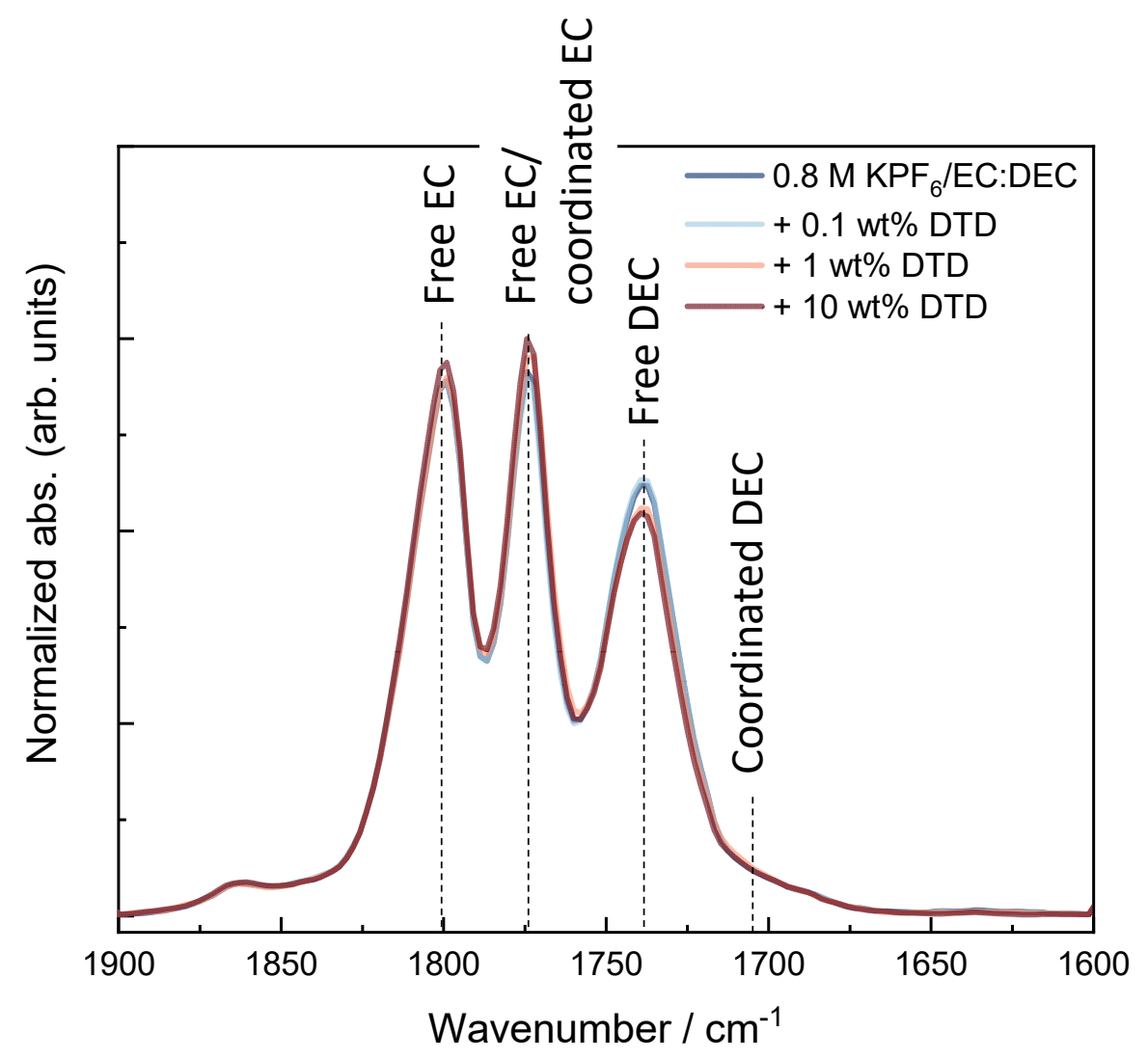

Figure S4. ATR-FTIR spectra of carbonyl group ( $\mathrm{C}=\mathrm{O}$ stretching) in $0.8 \mathrm{M}$ $\mathrm{KPF}_{6} / \mathrm{EC}: \mathrm{DEC}$ solutions with $0,0.1,1$, and 10 wt\% DTD. The $\mathrm{C}=\mathrm{O}$ stretching band of free EC is observed at $1805 \mathrm{~cm}^{-1}$, and the Fermi resonance is observed at $1770 \mathrm{~cm}^{-1}$. The band of coordinated EC overlaps the Fermi resonance of free EC. The $C=0$ stretching band of free EC is observed at 1805 $\mathrm{cm}^{-1}$. The free DEC has a band at $1740 \mathrm{~cm}^{-1}$, and the coordinated DEC has a band at the lower wavenumber. ${ }^{1}$ 


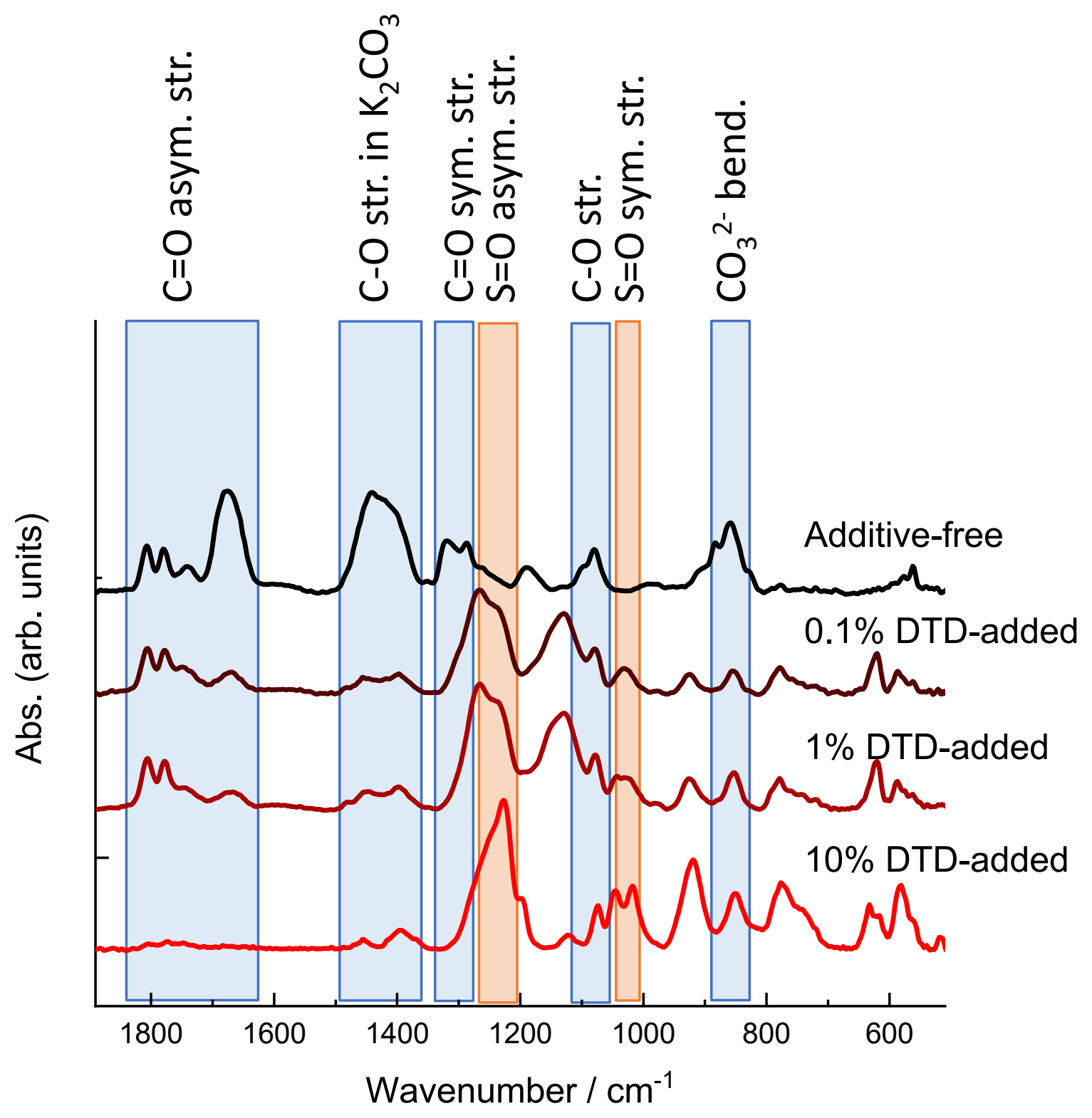

Figure S5. ATR-FTIR spectra of $K$ metal electrodes soaked in $0.8 \mathrm{M}$ $\mathrm{KPF}_{6} / \mathrm{EC}$ :DEC solutions with $0,0.1,1$, and $10 \mathrm{wt} \%$ DTD for three days in the glovebox equipped with cold trap. The $\mathrm{K}$ metal electrodes were rinsed with DME for two times. All measurements were conducted in the glovebox. 

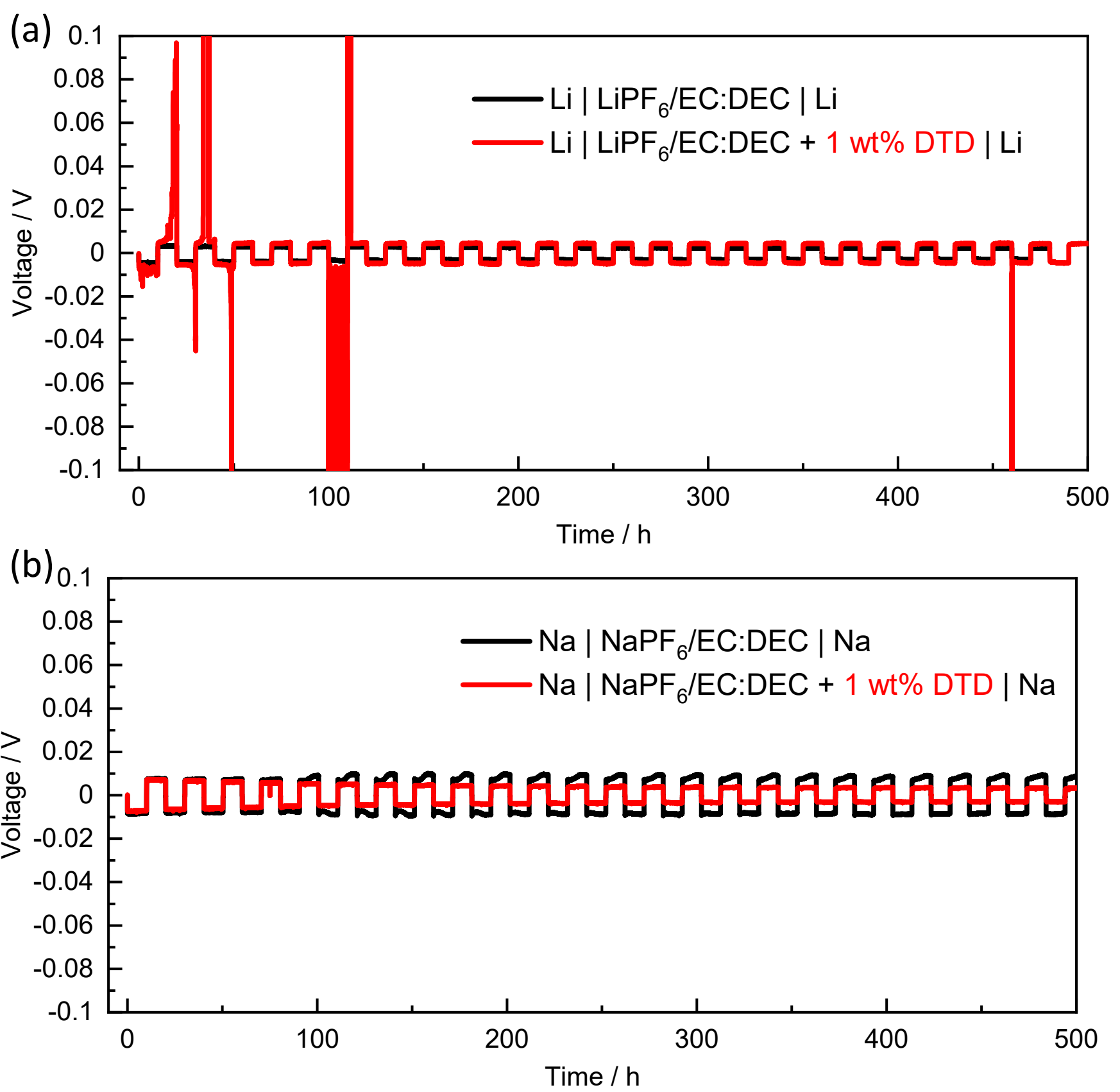

Figure S6. Voltage profiles of repeated (a) Li plating/stripping and (b) Na plating/stripping in A || A cells filled with $1 \mathrm{M} \mathrm{APF}_{6} / \mathrm{EC}: \mathrm{DEC}(\mathrm{A}=\mathrm{Li}$ or $\mathrm{Na})$ with or without $1 \mathrm{wt} \% \mathrm{DTD}$. 


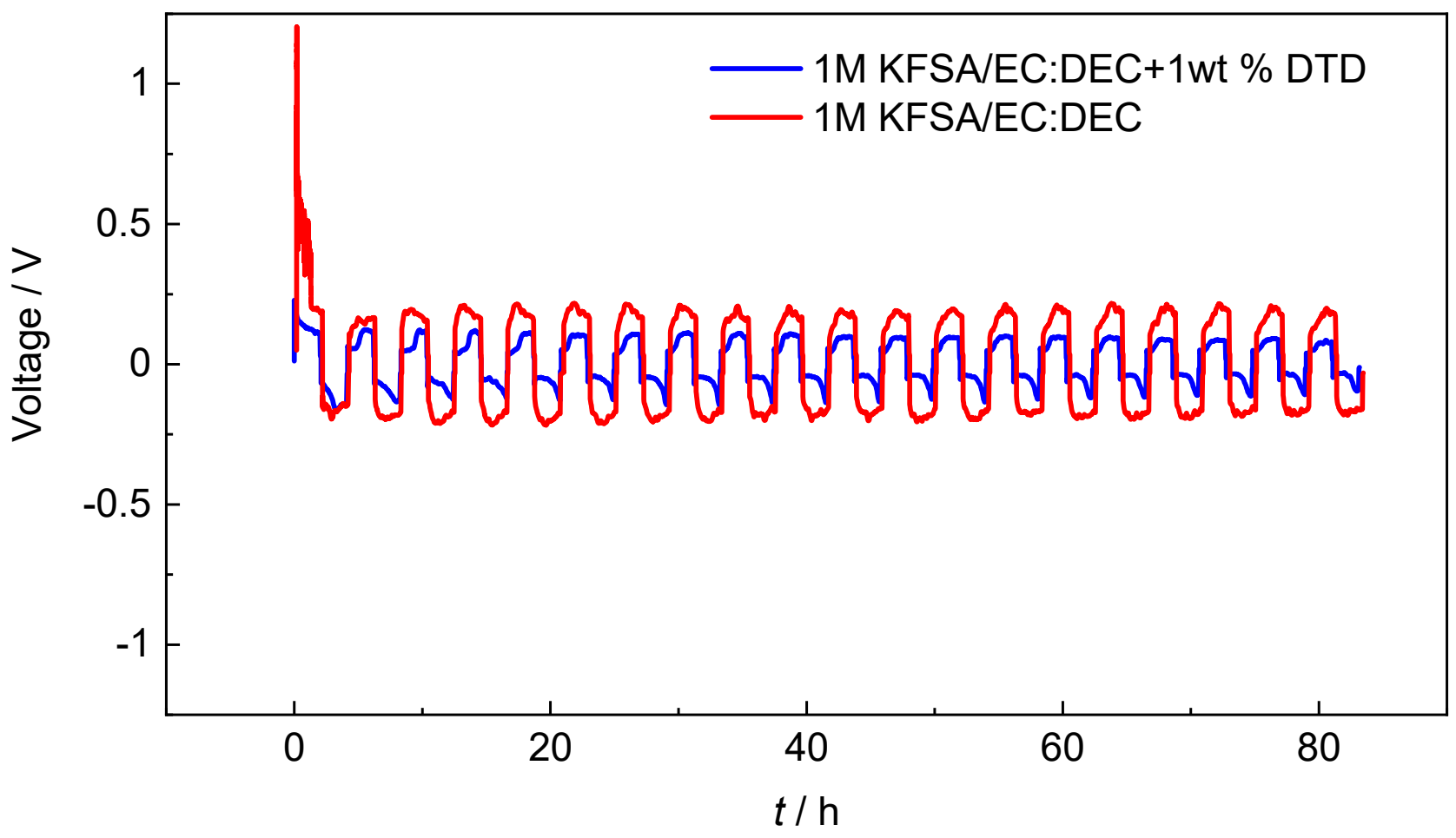

Figure S7. Voltage profiles of repeated K plating/stripping in K || K cells filled with 1 M KFSA/EC:DEC with or without 1 wt\% DTD. 
(a)

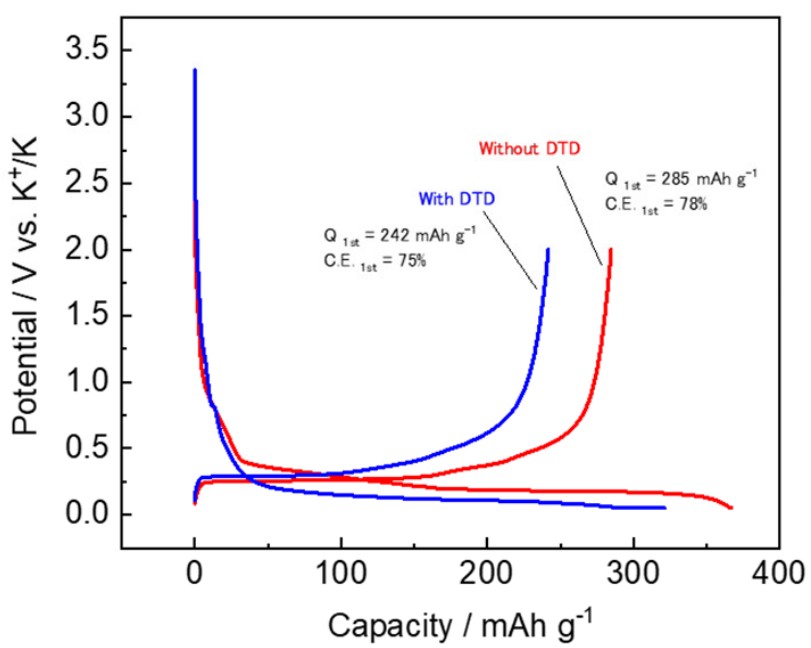

(b)

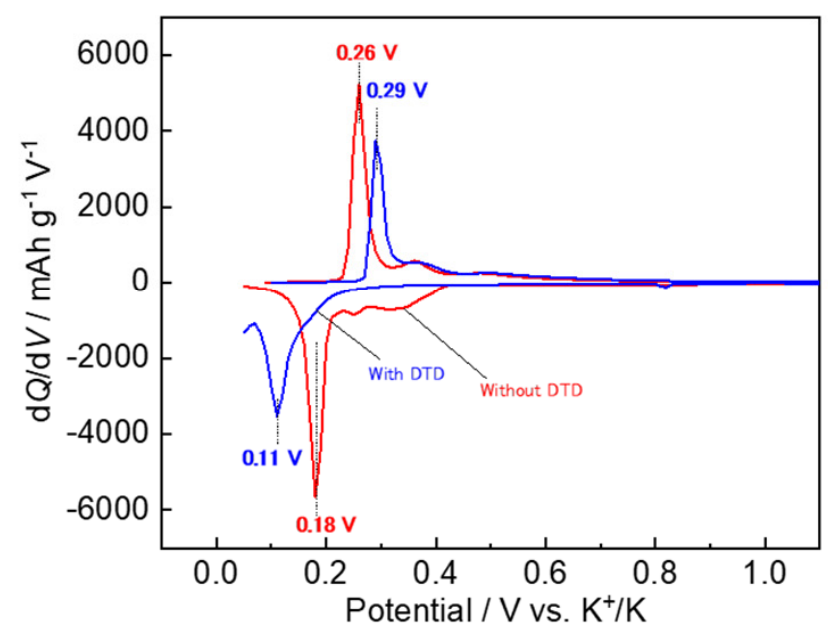

Figure S8. (a) Charge discharge curves and (b) $d Q / d V$ curves of graphite electrodes in $K$ cells filled with $1 \mathrm{M} \mathrm{KFSA/EC:DEC}$ with or without 1 wt\% DTD. 

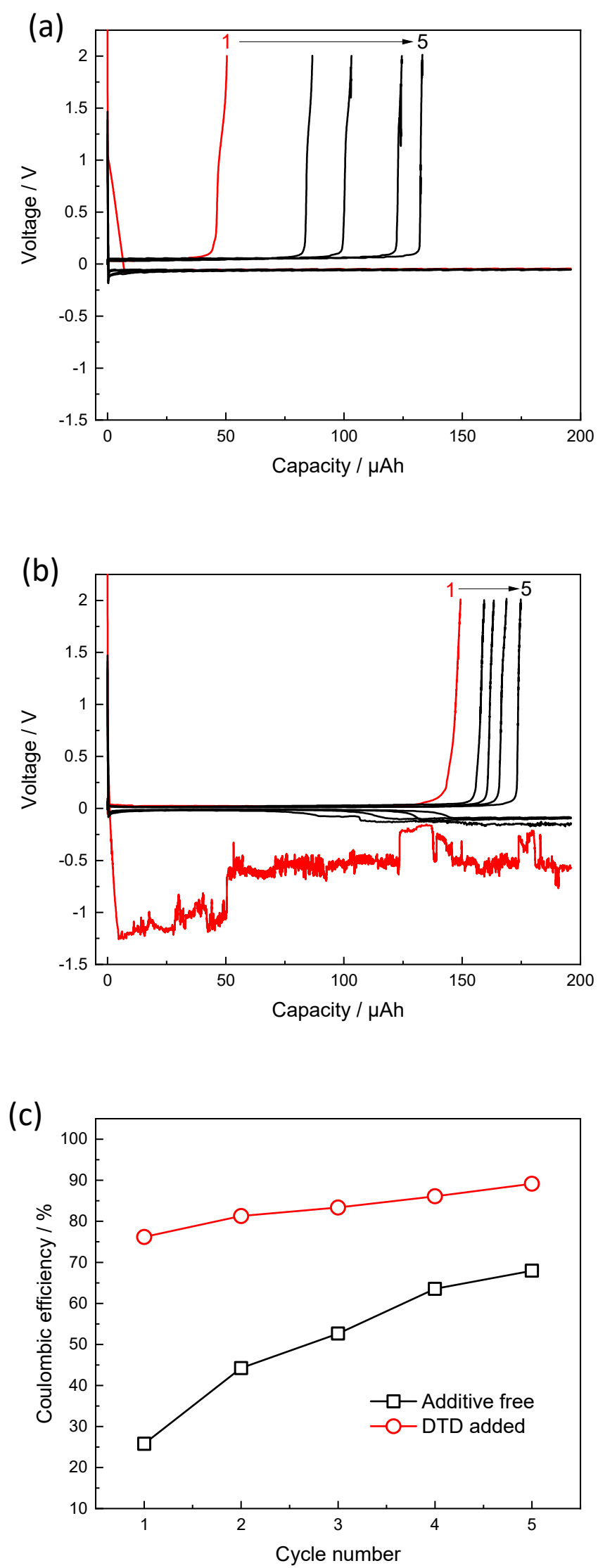

Figure S9. Voltage profiles of repeated $\mathrm{K}$ plating/stripping in $\mathrm{K} / / \mathrm{Cu}$ cells filled with (a) 0.8 $\mathrm{M} \mathrm{KPF}_{6} / \mathrm{EC}: \mathrm{DEC}$ and (b) $0.8 \mathrm{M} \mathrm{KPF}_{6} / \mathrm{EC}: \mathrm{DEC}+1 \mathrm{wt} \%$ of DTD. (c) Variations of Coulombic efficiencies of the cells. The solid lines in (c) are guide to the eye. 

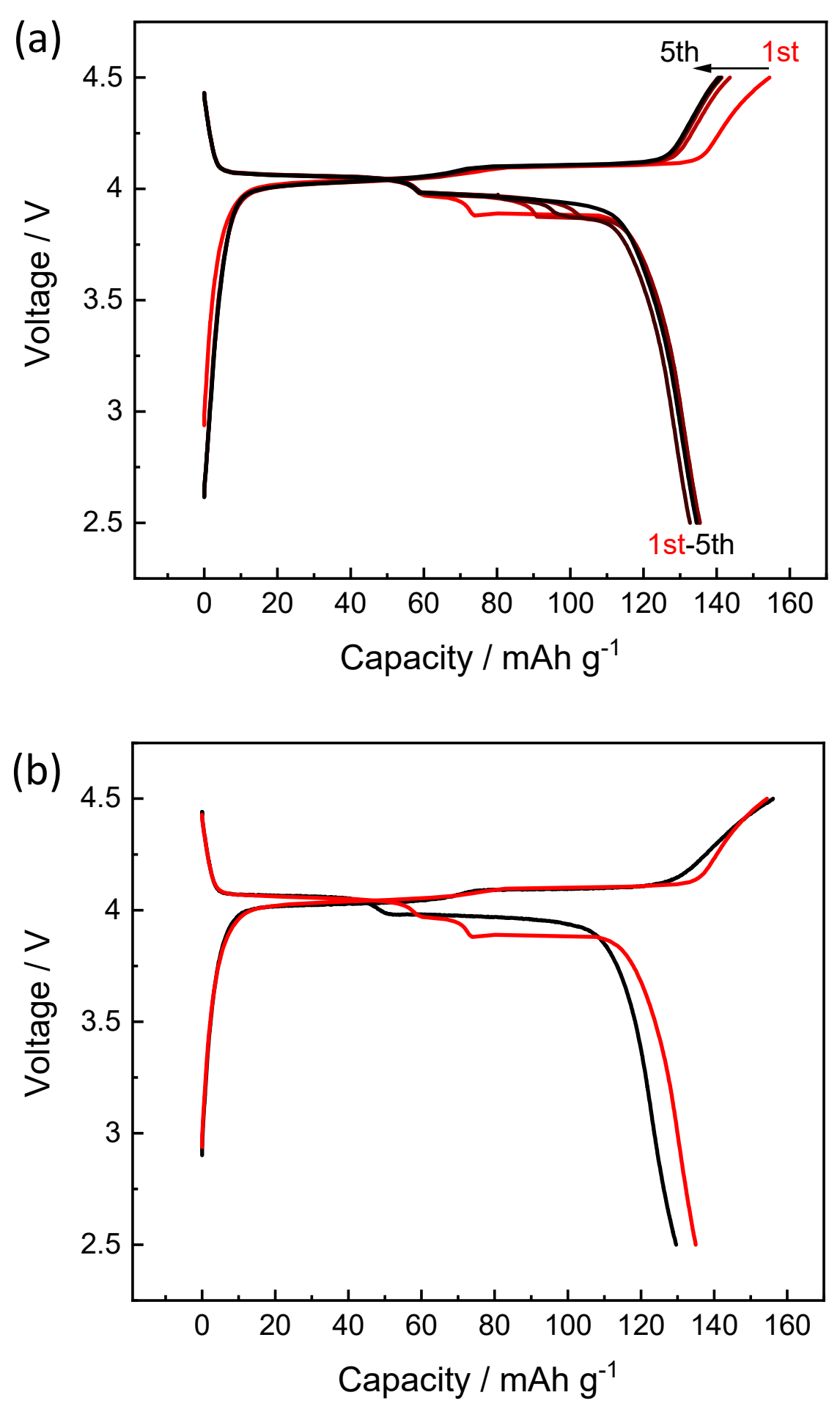

Figure S10. (a) Charge-discharge curves of $\mathrm{K} \| \mathrm{K}{ }_{2} \mathrm{Mn}\left[\mathrm{Fe}(\mathrm{CN})_{6}\right]$ cells filled with 0.8 $\mathrm{M} \mathrm{KPF}_{6} / \mathrm{EC}: \mathrm{DEC}+1 \mathrm{wt} \%$ of DTD fabricated in the glovebox without cold trap and (b) comparison of the charge-discharge curves with or without cold trap. 
(a)

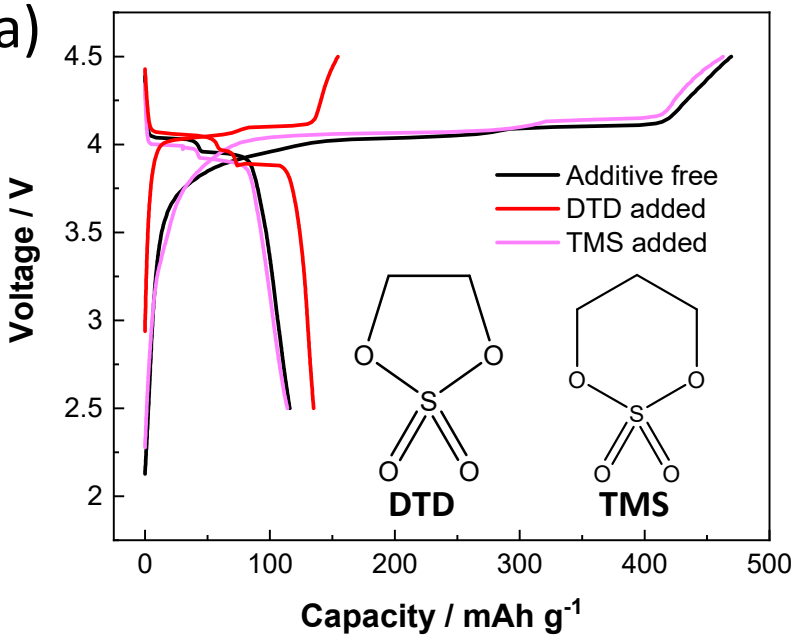

(b)

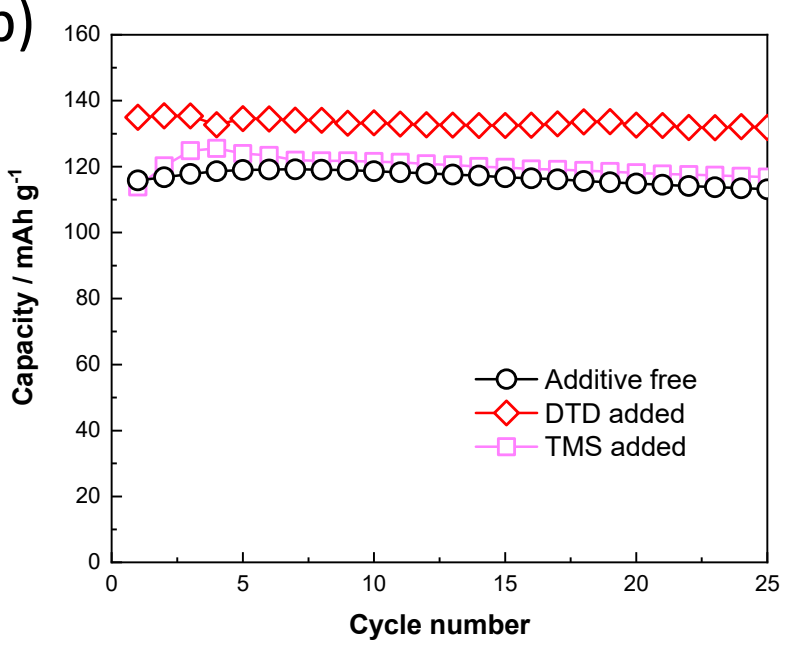

(c)

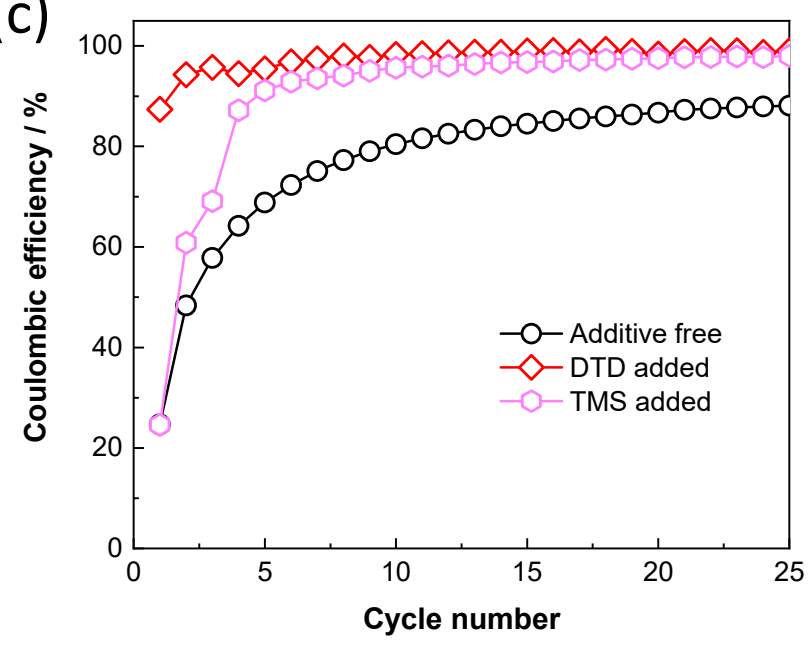

Figure S11. (a) Charge-discharge curves of $\mathrm{K} \| \mathrm{K}_{2} \mathrm{Mn}\left[\mathrm{Fe}(\mathrm{CN})_{6}\right]$ cells filled with $0.8 \mathrm{M} \mathrm{KPF}_{6} / \mathrm{EC}: \mathrm{DEC}$ with or without $1 \mathrm{wt} \%$ of TMS, or DTD. Their (b) cycle performance and (c) Coulombic efficiency. 

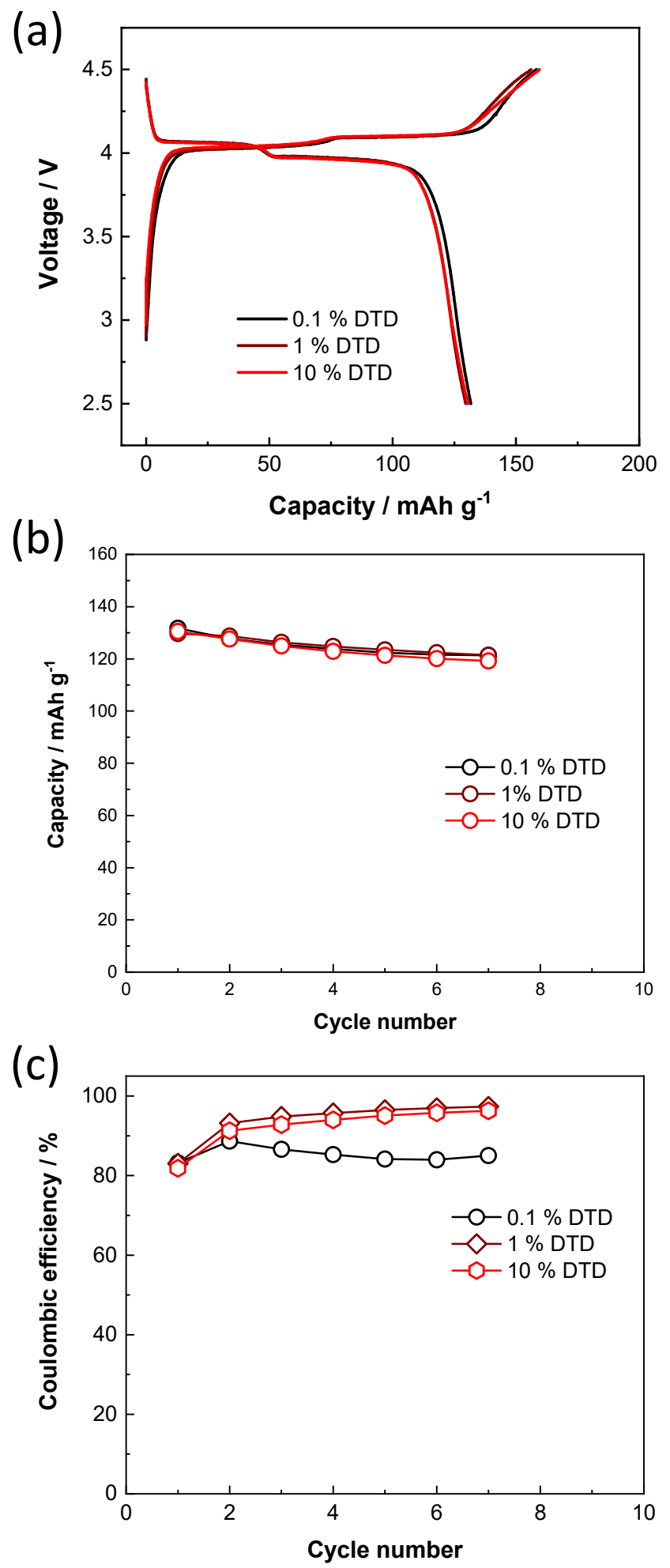

Figure S12. (a) Charge-discharge curves of $\mathrm{K} \| \mathrm{K}_{2} \mathrm{Mn}\left[\mathrm{Fe}(\mathrm{CN})_{6}\right]$ cells filled with $0.8 \mathrm{M} \mathrm{KPF}_{6} / \mathrm{EC}: \mathrm{DEC}$ with $0.1,1$, and $10 \mathrm{wt} \%$ DTD. Their (b) cycle performance and (c) Coulombic efficiency. 

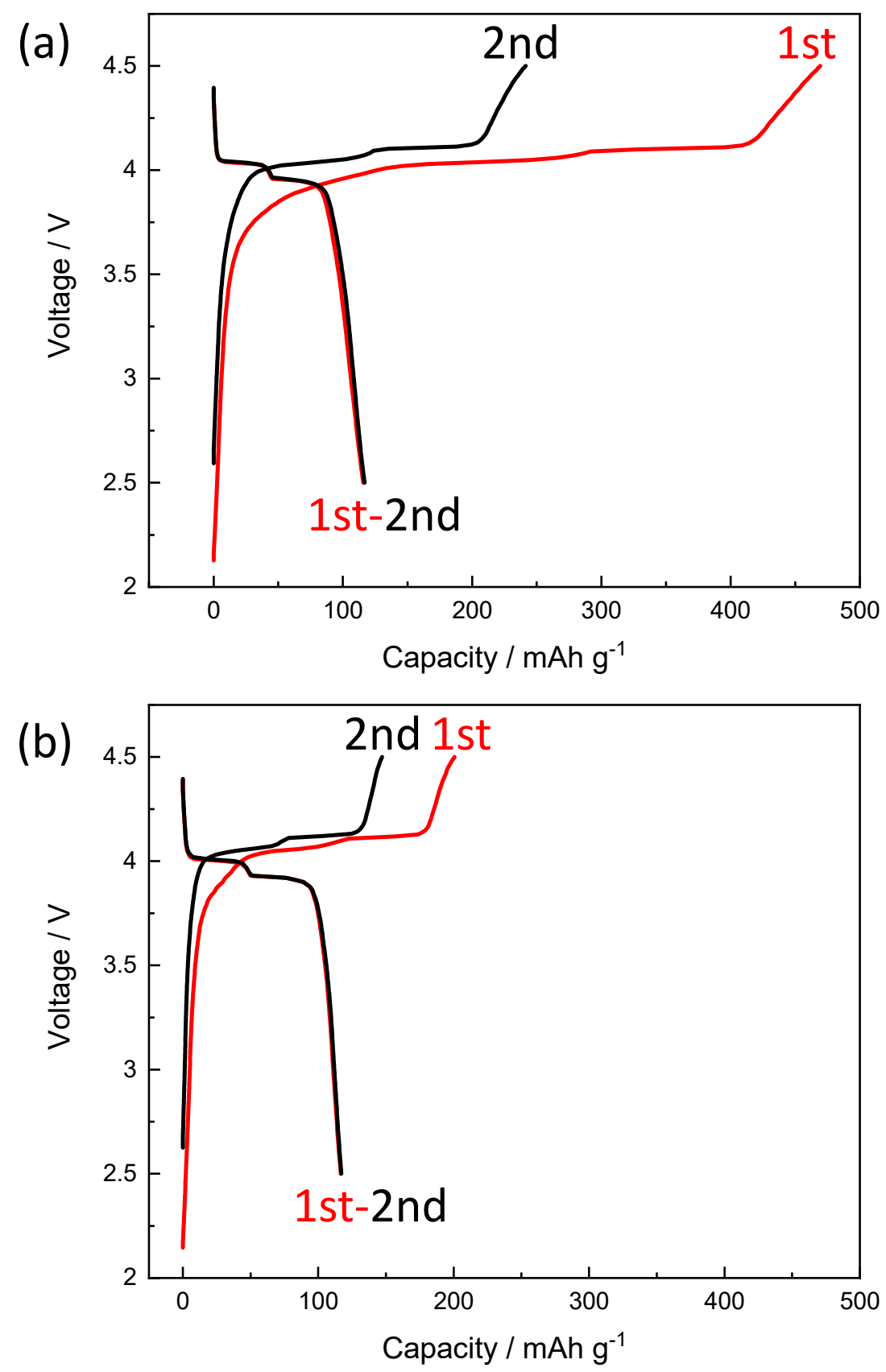

Figure S13. Charge-discharge curves of $\mathrm{K} \| \mathrm{K}_{2} \mathrm{Mn}\left[\mathrm{Fe}(\mathrm{CN})_{6}\right]$ cells filled with 0.8 $\mathrm{M} \mathrm{KPF}_{6} / \mathrm{EC}: \mathrm{DEC}$ with (a) non-pretreated $\mathrm{K}$ metal counter electrode or (b) pretreated $\mathrm{K}$ metal counter electrode by 1 wt\% DTD-added electrolyte. The pretreatment of the electrolyte was conducted by immersing a $\mathrm{K}$ metal electrode in $0.8 \mathrm{M} \mathrm{KPF}_{6} / \mathrm{EC}: \mathrm{DEC}+1 \mathrm{wt} \%$ DTD additive for three days. The Kmetal was removed from the solution and the remaining solution was lightly wiped off before being used for testing in the DTD-free electrolyte. 

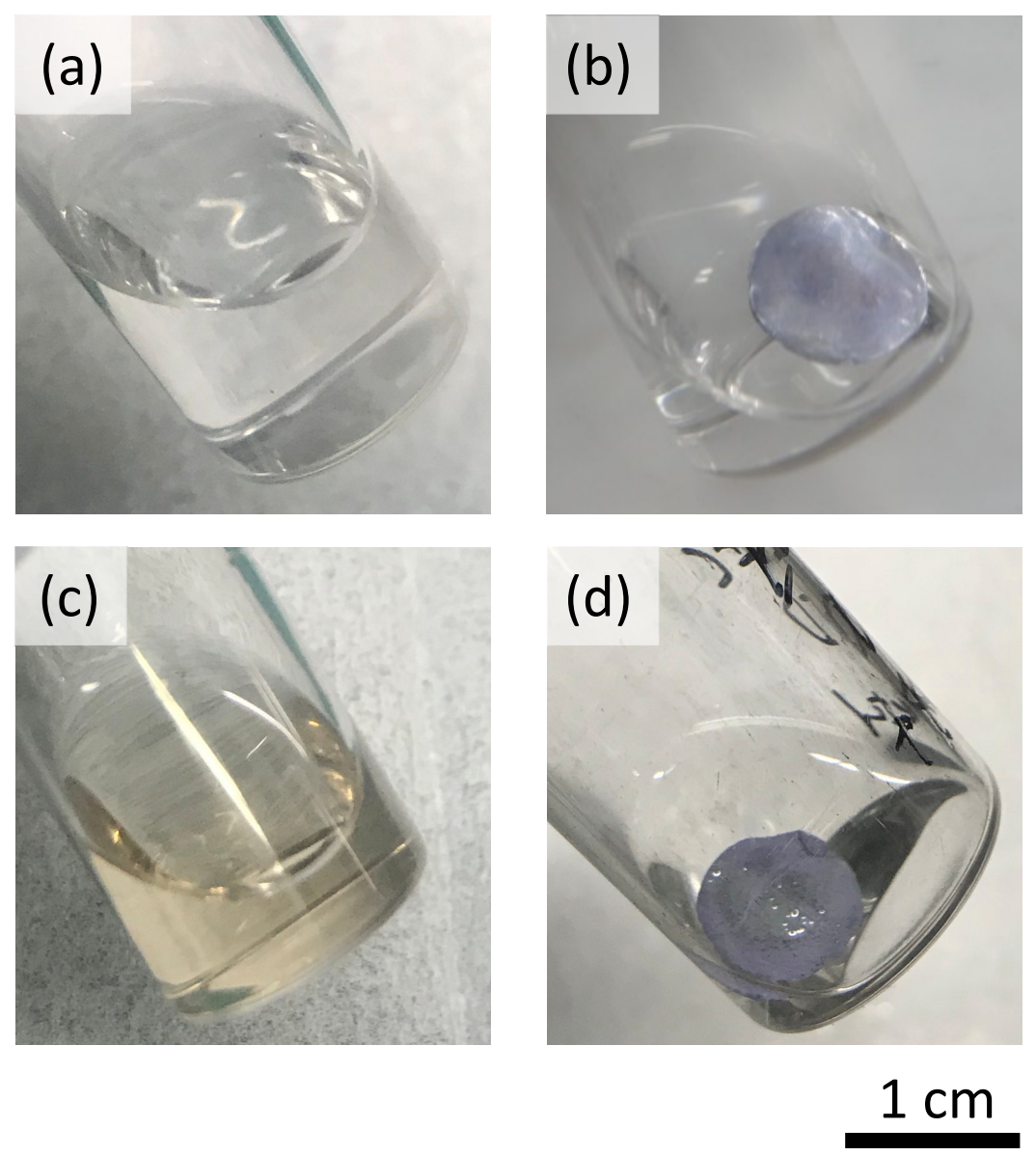

Figure S14. Photographs of electrolytes and/or $K$ metal discs of the $\mathrm{KPF}_{6} / \mathrm{EC}: \mathrm{DEC}(\mathrm{a})$ before and (b) after $\mathrm{K}$ metal immersion for $14 \mathrm{~d}, \mathrm{KPF}_{6} / \mathrm{EC}: \mathrm{DEC}$ +1 wt\% DTD (c) before and (d) after K metal immersion for $14 \mathrm{~d}$. 


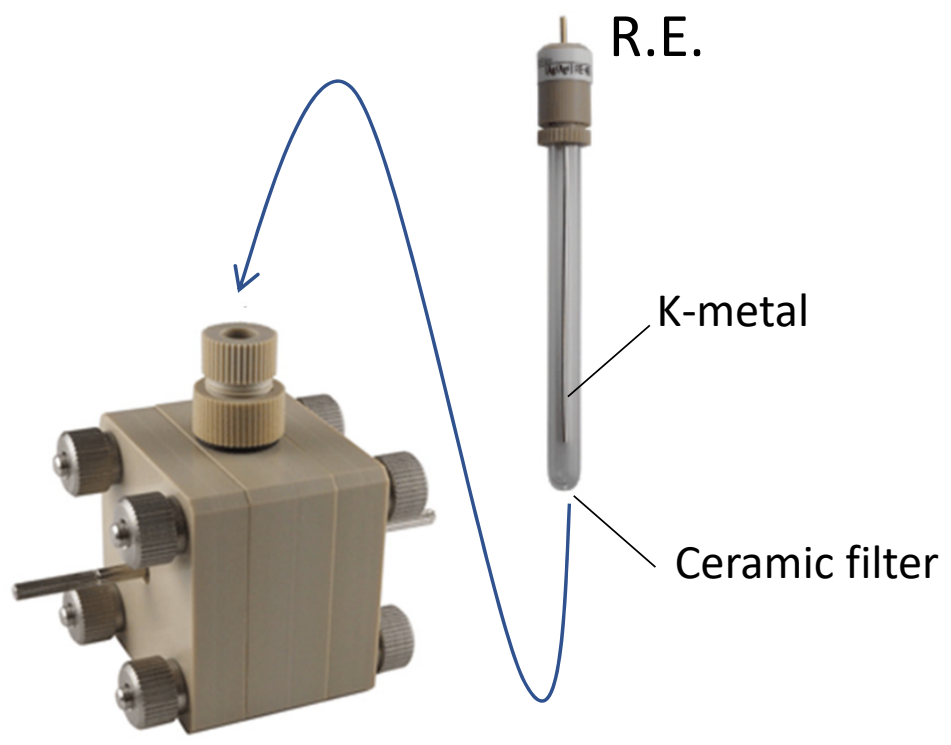

WE: Al foil

CE: Activated carbon electrode

Figure S15. (a) Photograph of the three electrode cell for linear sweep voltammetry and its configuration. 
(a)

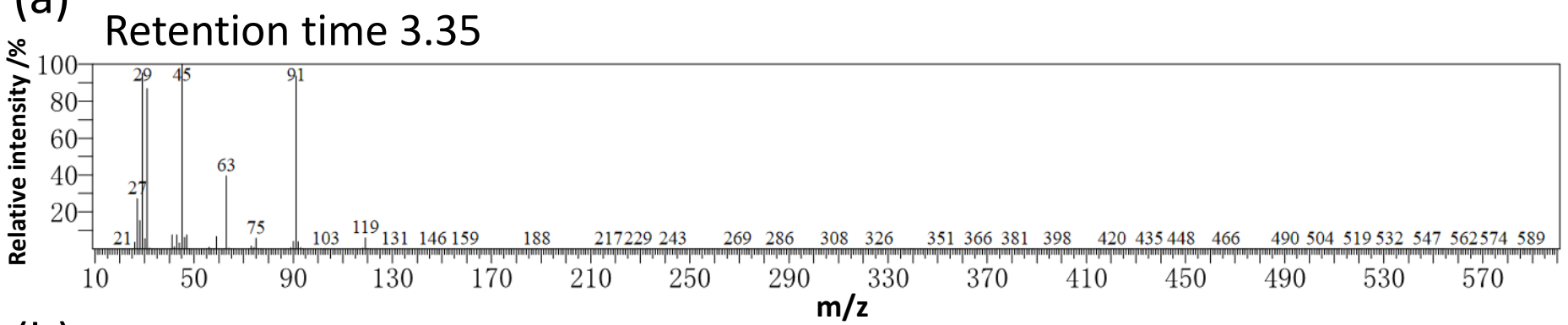

(b) DEC, NIST20 (\#4638), Similarity Index:92

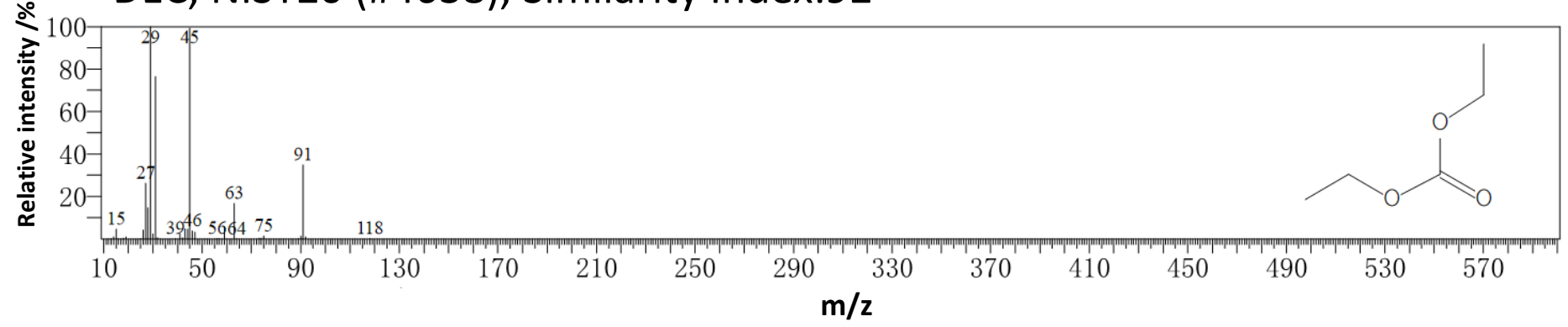

Figure S16. (a) El mass spectrum of the peak with retention time of 3.35 in Figure 3 and (b) mass spectrum of DEC from NIST20 library. 
(a) Retention time 10.84

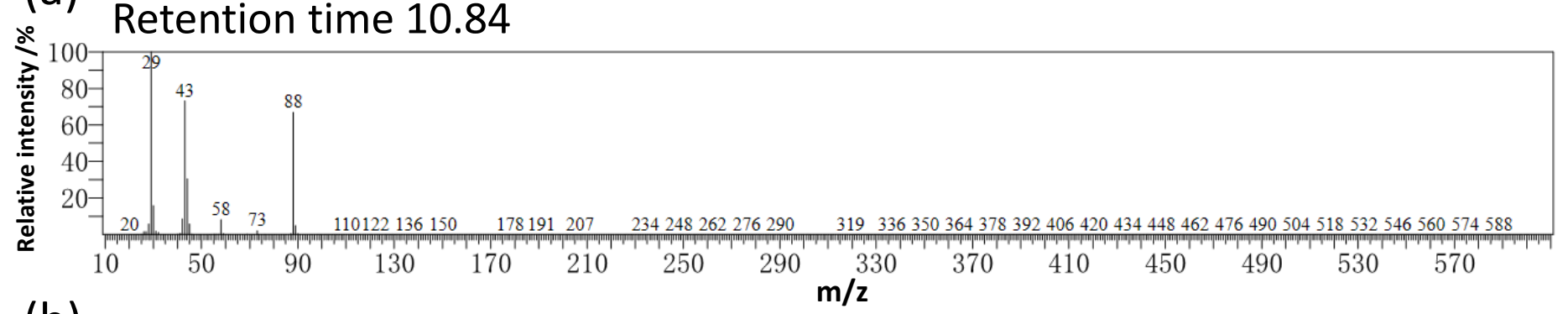

(b) EC, NIST20 (\#1193), Similarity Index:98

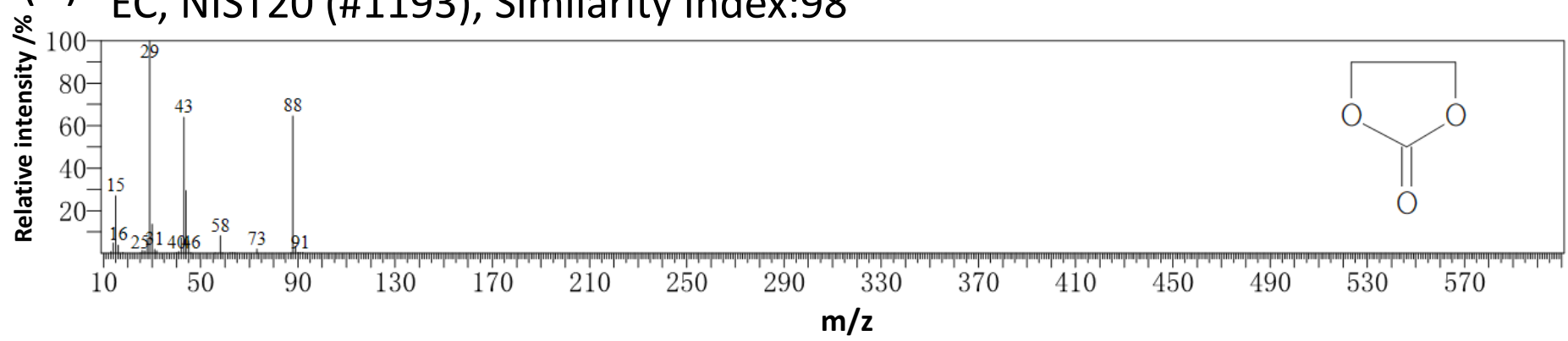

Figure S17. (a) El mass spectrum of the peak with retention time of 10.84 in Figure 3 and (b) mass spectrum of EC from NIST20 library. 
(a) Retention time 12.055

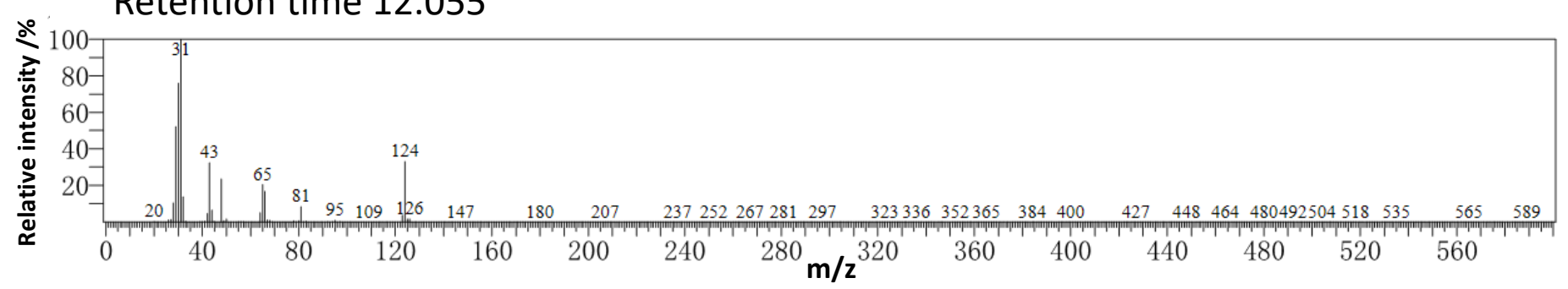

(b) 1,3,2-Dioxathiolane 2,2-dioxide, NIST20 (\#6251), Similarity Index:89

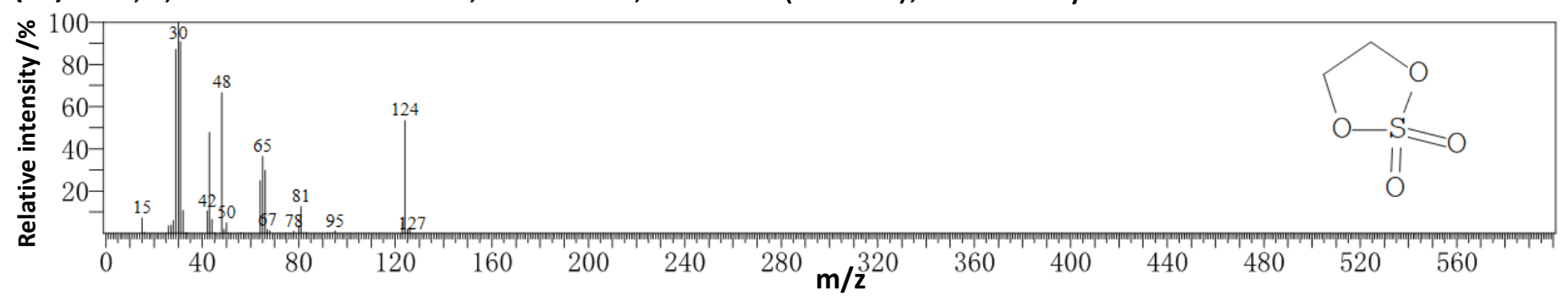

Figure S18. (a) El mass spectrum of the peak with retention time of 12.055 in Figure 3 and (b) mass spectrum of DTD from NIST20 library. 


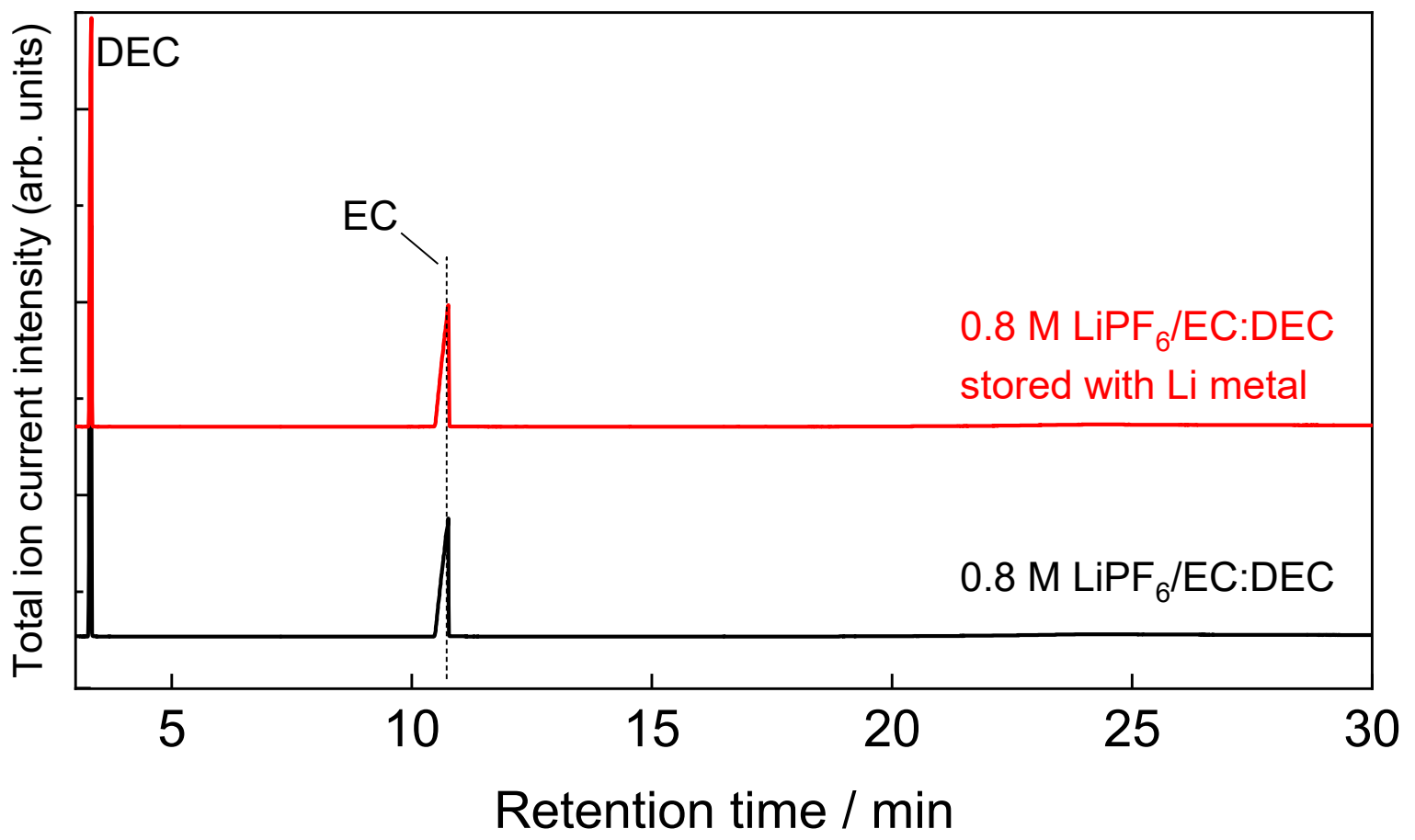

Figure S19. TIC chromatogram of $0.8 \mathrm{M} \mathrm{LiPF}_{6} / \mathrm{EC}: \mathrm{DEC}$ stored with or without Li metal for three days. 
(a)

$\# 1$, Retention time 13.16

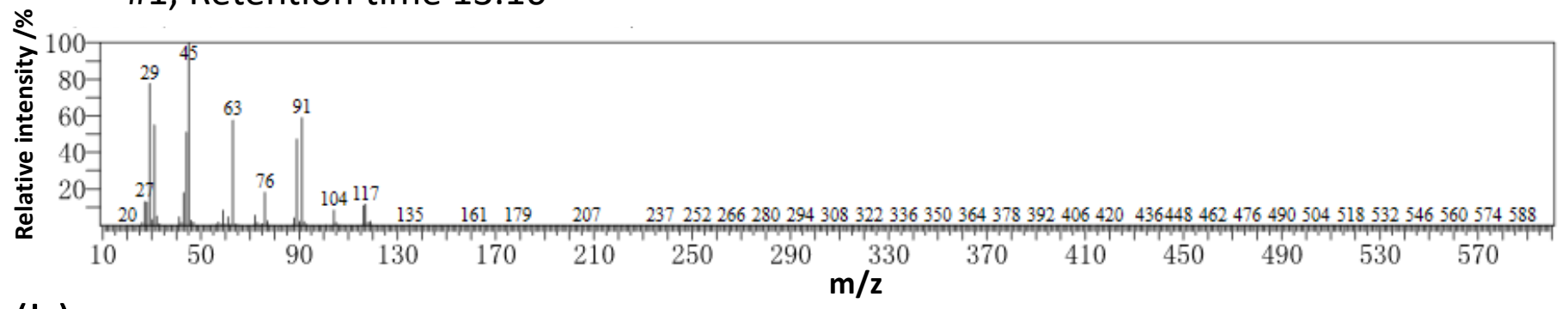

(b) Diethyl pyrocarbonate $\left(\mathrm{C}_{6} \mathrm{H}_{10} \mathrm{O}_{5}\right), \mathrm{MW}: 162, \mathrm{NIST} 20$ (\#23801), Similarity Index:81

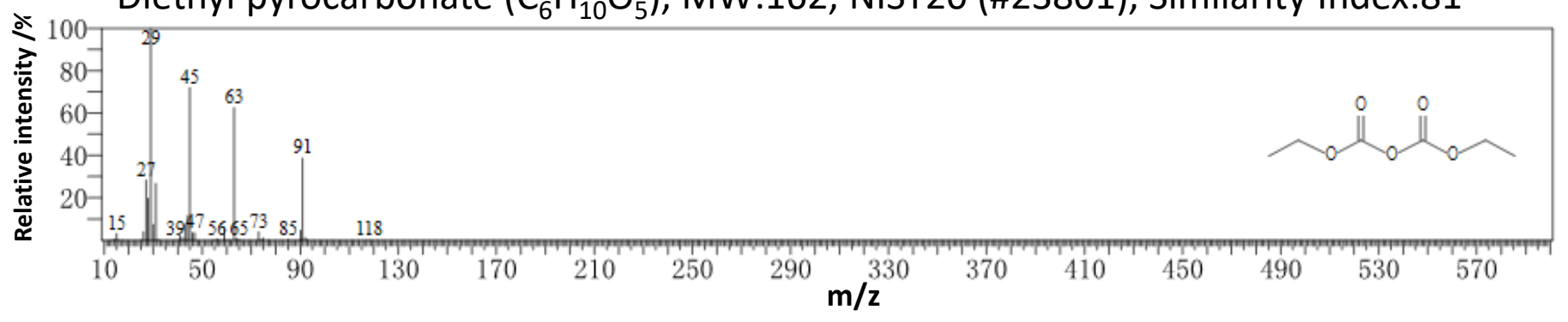

(c) Diethyl 2,5-Dioxahexanedioate $\left(\mathrm{C}_{8} \mathrm{H}_{14} \mathrm{O}_{6}\right), \mathrm{MW}: 206$,

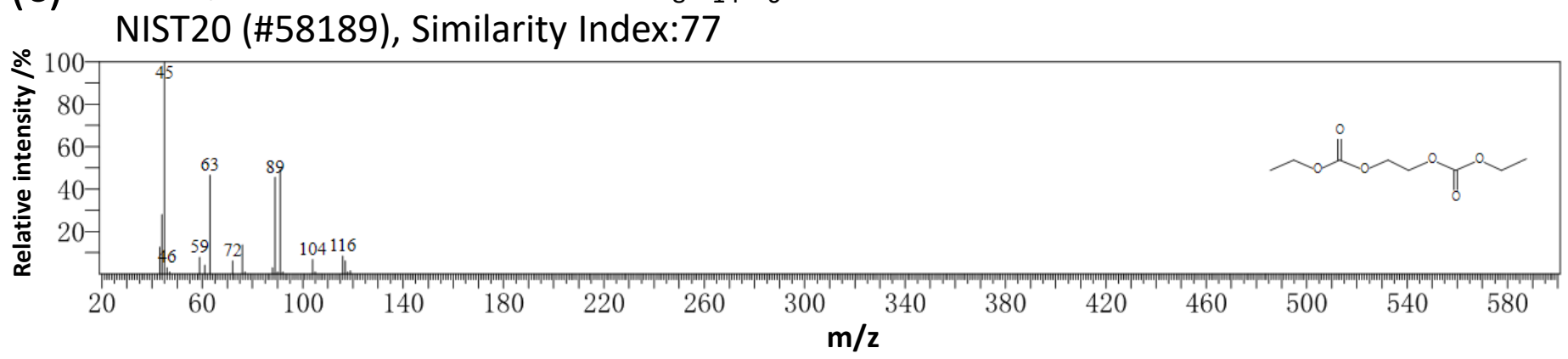

Figure S20. (a) El mass spectrum of the peak \#1 with retention time of 13.16 in Figure 3 and mass spectra of (b) diethyl pyrocarbonate and (c) diethyl 2,5-dioxahexanedioate, which have high similarity index with the peak \#1. 
(a)

\#2, Retention time 16.085

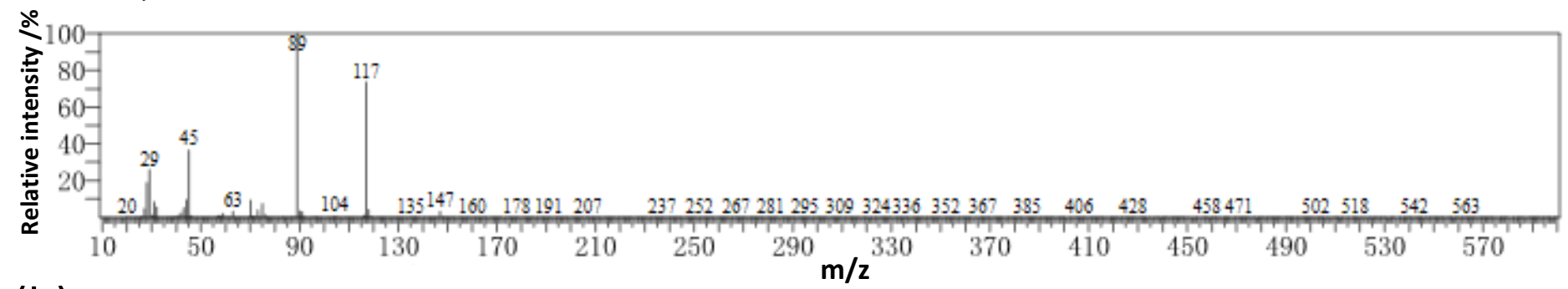

(b) Methyl pyruvate dimethyl acetal $\left(\mathrm{C}_{6} \mathrm{H}_{12} \mathrm{O}_{4}\right), \mathrm{MW}: 148, \mathrm{NIST} 20$ (\#15949), Similarity Index:74

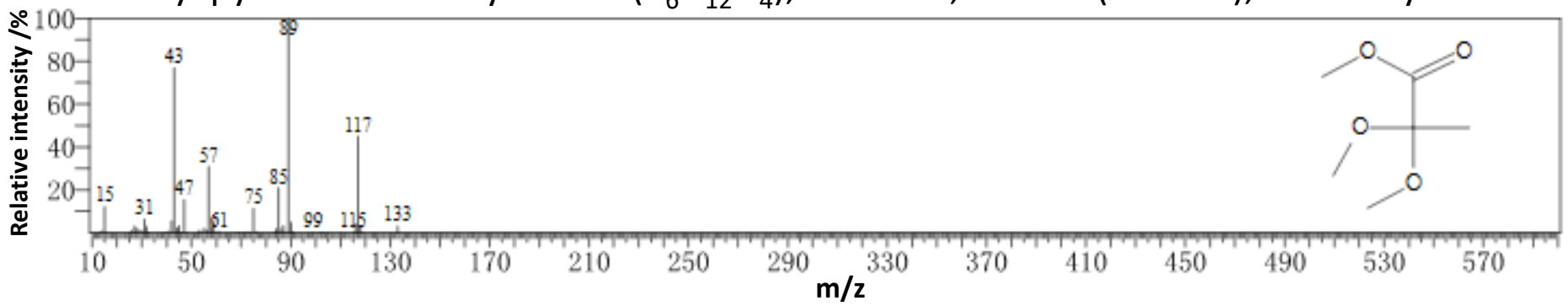

(c) Dimethyl 2,2'-(2,2'-oxybis(ethane-2,1-diyl)bis(oxy)) diacetate $\left(\mathrm{C}_{10} \mathrm{H}_{18} \mathrm{O}_{7}\right), \mathrm{MW}: 250$ $\curvearrowright_{100}$ NIST20 (\#104339), Similarity Index:74

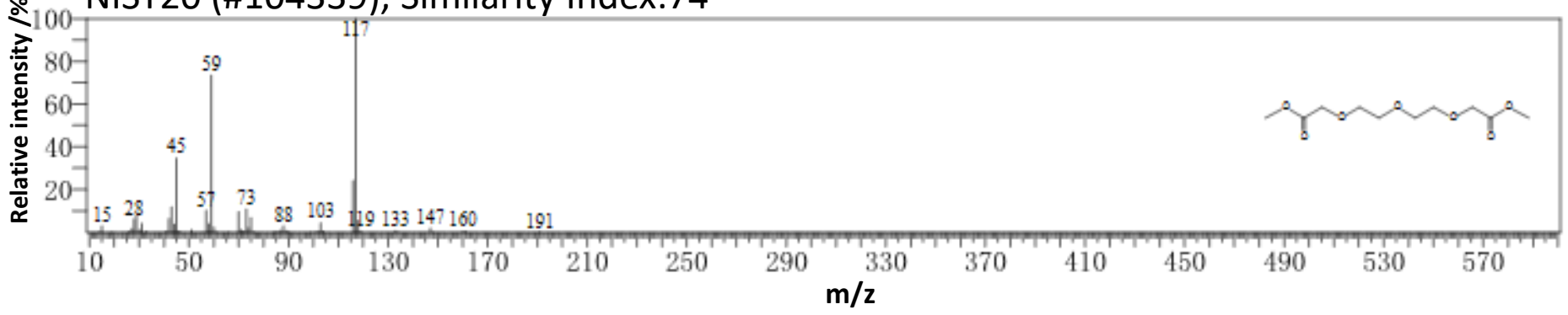

Figure S21. (a) El mass spectrum of the peak \#2 with retention time of 16.085 in Figure 3 and mass spectra of (b) methyl pyruvate dimethyl acetal and (c) dimethyl 2,2'-(2,2'oxybis(ethane-2,1-diyl)bis(oxy))diacetate, which have high similarity index with the peak \#2. 
(a) \#3, Retention time 18.555

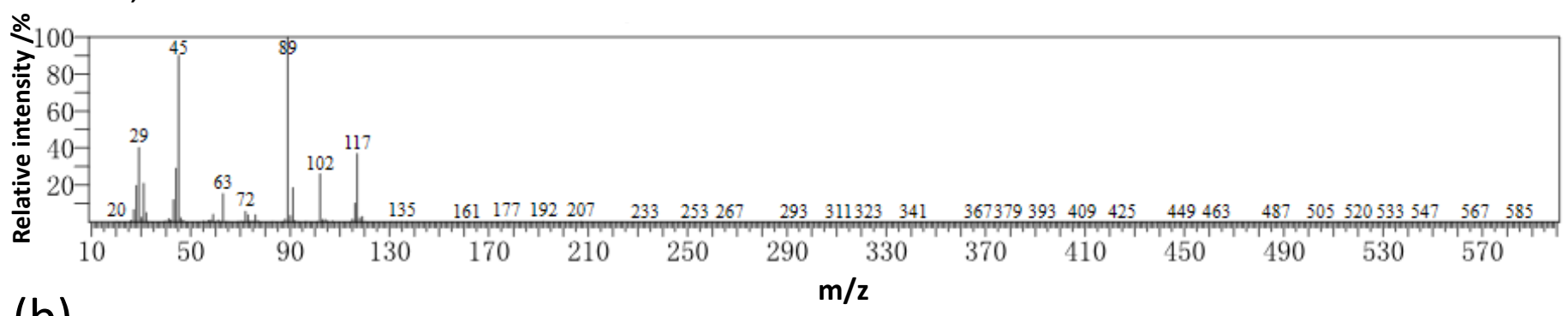

(b) 2-(2-Ethoxyethoxy)ethyl isobutyl carbonate $\left(\mathrm{C}_{11} \mathrm{H}_{22} \mathrm{O}_{5}\right), \mathrm{MW}: 234$,

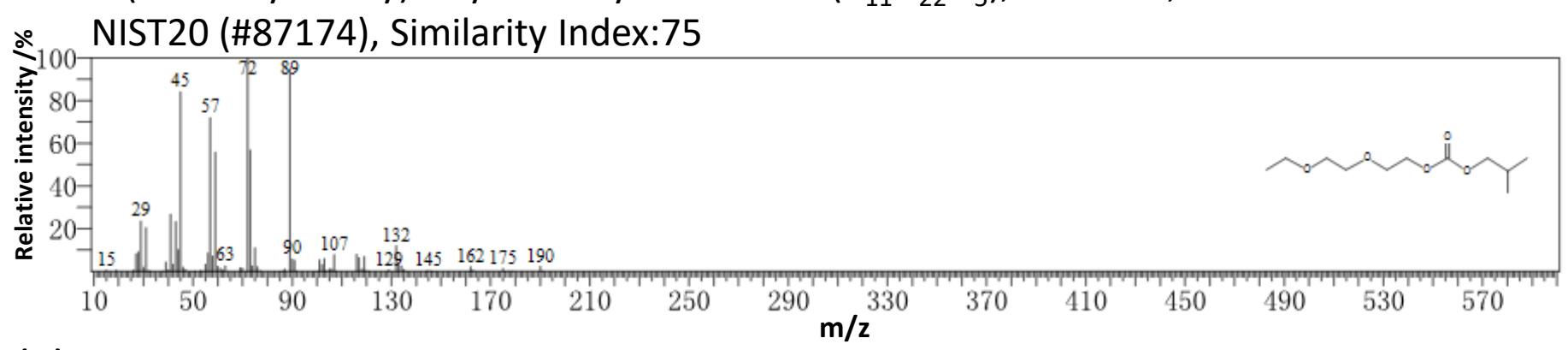

(c) Methoxytriethylene glycol $\left(\mathrm{C}_{7} \mathrm{H}_{16} \mathrm{O}_{4}\right)$, MW:164, NIST20 (\#14408), Similarity Index:75

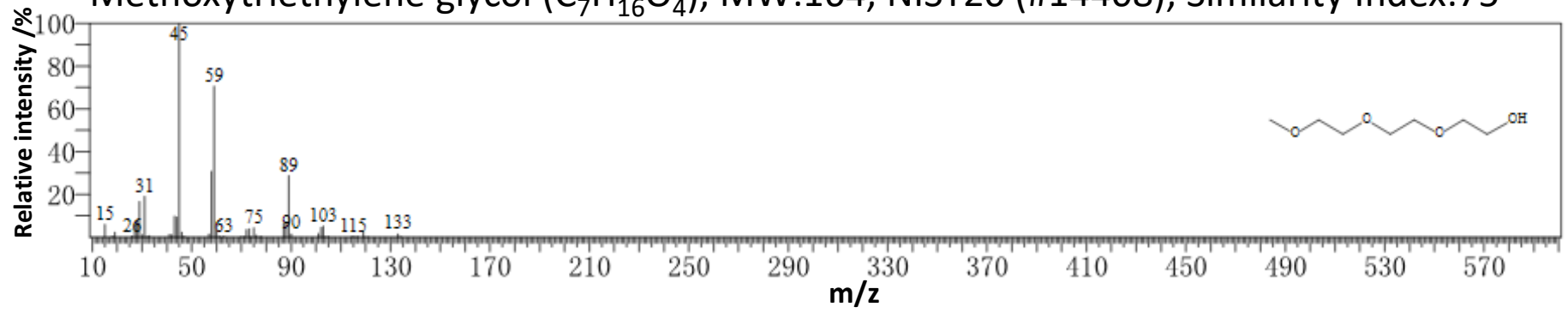

Figure S22. (a) El mass spectrum of the peak \#3 with retention time of 18.555 in Figure 3 and mass spectra of (b) 2-(2-Ethoxyethoxy)ethyl isobutyl carbonate and (c) methoxytriethylene glycol, which have high similarity index with the peak \#3. 
(a)

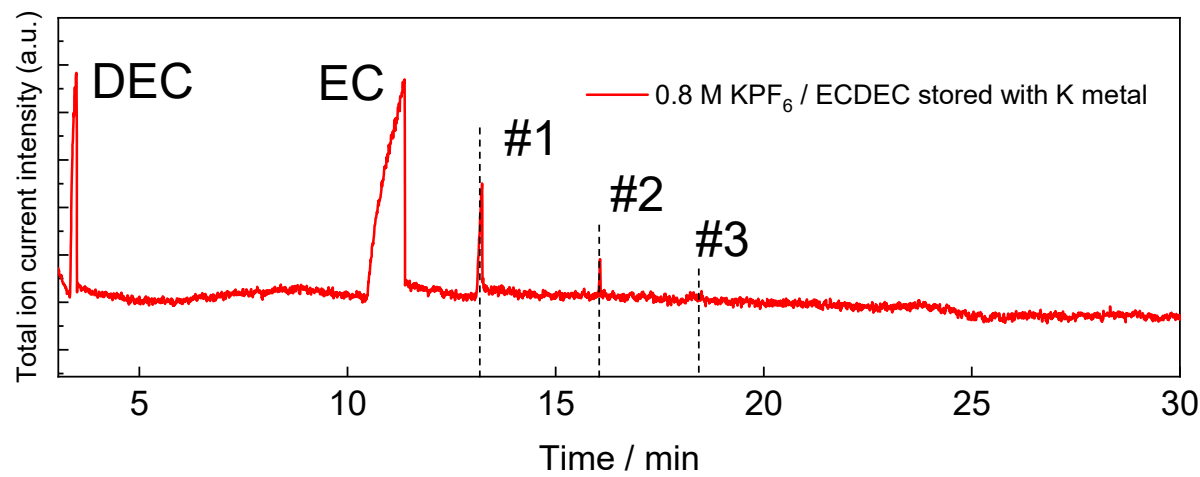

(b)

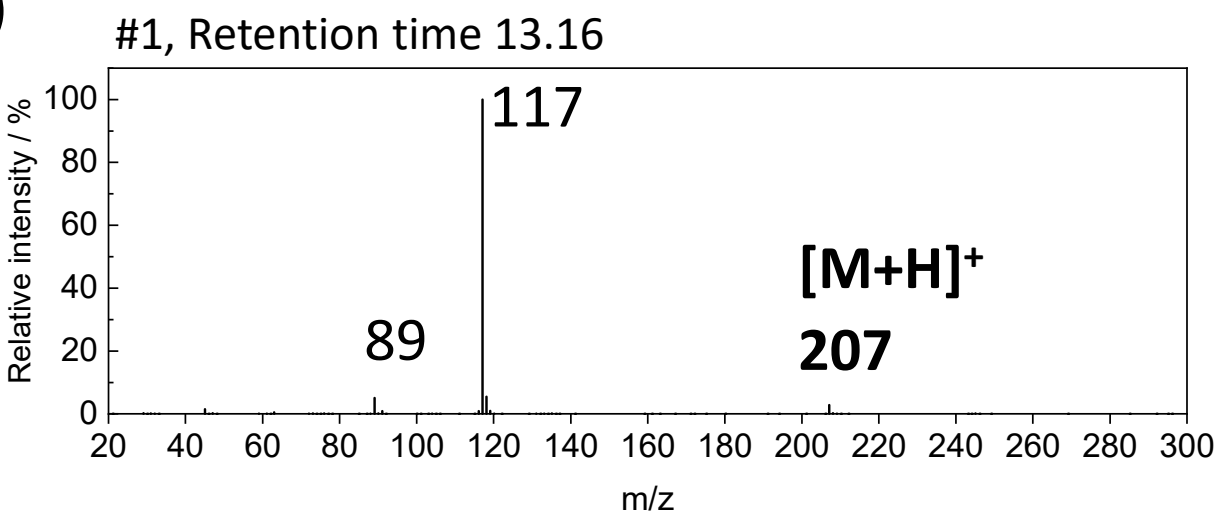

(c) \#2, Retention time 16.085

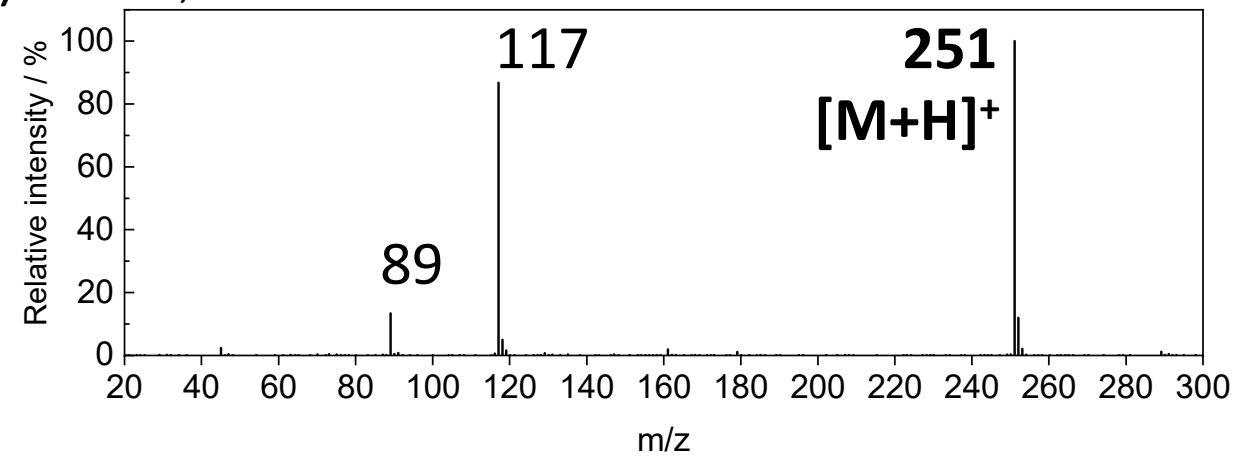

(d) $\quad \# 3$, Retention time 18.555

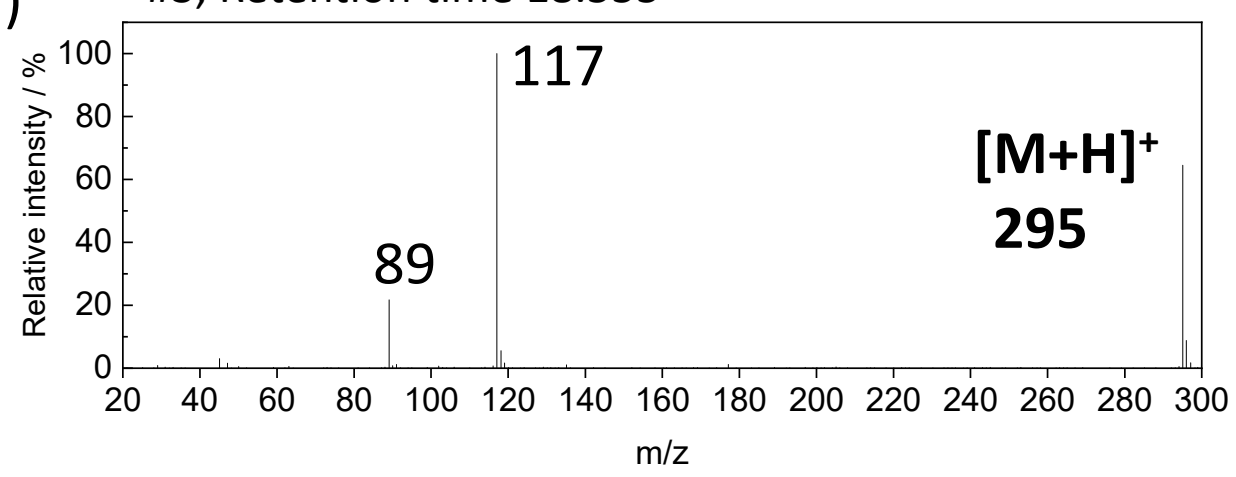

Figure S23. GC-PCI-MS analysis of $0.8 \mathrm{M} \mathrm{KPF}_{6} / \mathrm{EC}$ :DEC stored with $\mathrm{K}$ metal for three days: (a) TIC chromatogram, Cl mass spectra of the peaks (b) \#1, (c) \#2, and (d) \#3. 
(a) \#1<smiles>CCOC(=O)OCCOC(=O)OCC</smiles>

(b) \#2

(c) \#3<smiles>CCOC(=O)OCCOCCOC(=O)OCC</smiles><smiles>CCOCCOCCOCCOCCOC(=O)OCC</smiles>

Figure S24. Potential decomposition products of electrolyte reacted with $\mathrm{K}$ metal, (a) $\mathrm{C}_{8} \mathrm{H}_{14} \mathrm{O}_{6}$ (MW 206), (b) $\mathrm{C}_{10} \mathrm{H}_{18} \mathrm{O}_{7}$ (MW 250), and (c) $\mathrm{C}_{13} \mathrm{H}_{26} \mathrm{O}_{7}$ (MW 294). 
(a)
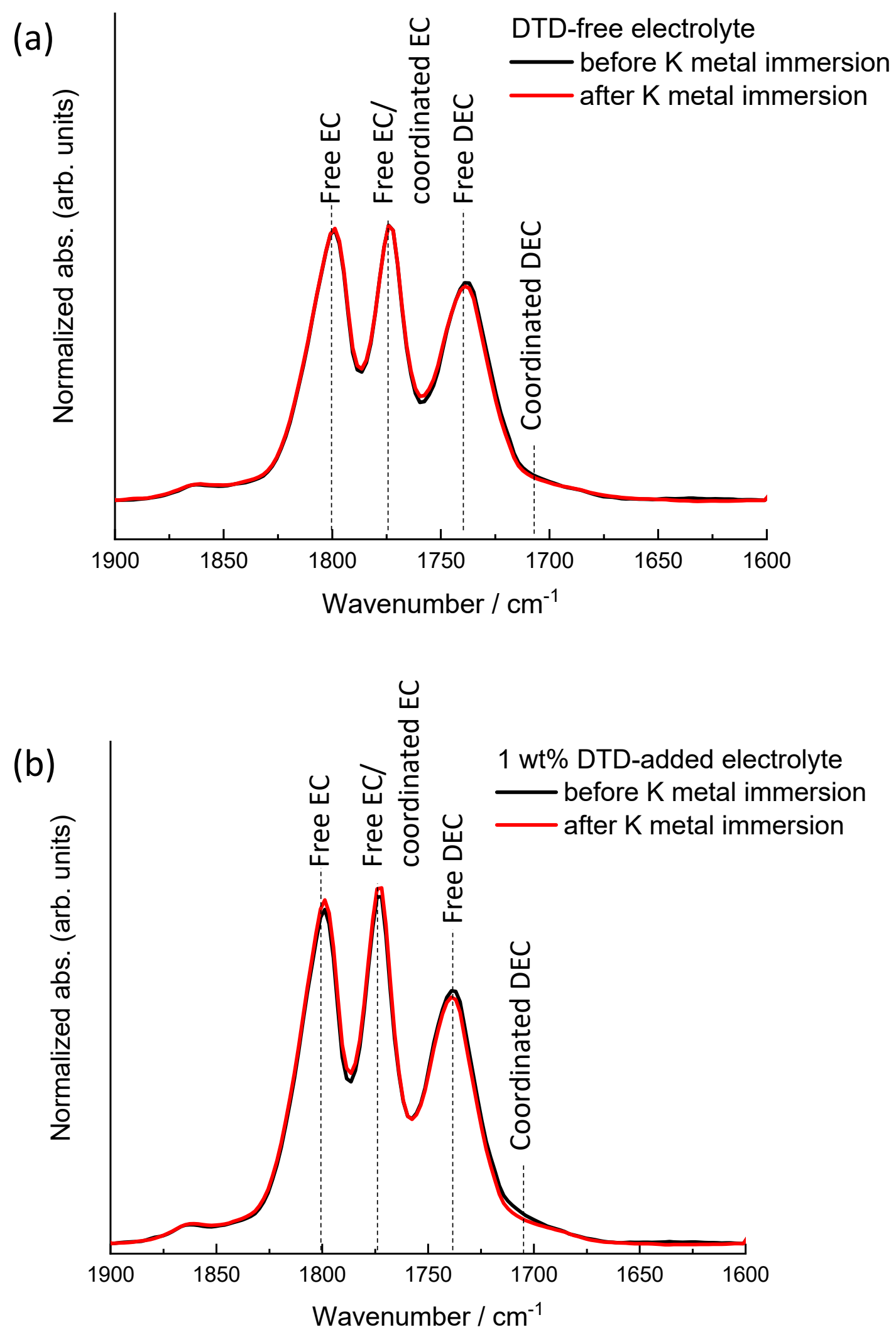

Figure S25. ATR-FTIR spectra of carbonyl group ( $C=0$ stretching) in $0.8 \mathrm{M}$ $\mathrm{KPF}_{6} / \mathrm{EC}: \mathrm{DEC}$ solutions (a) without DTD additive and with (b) 1 wt\% DTD additive before and after $\mathrm{K}$ metal immersion for three days. 


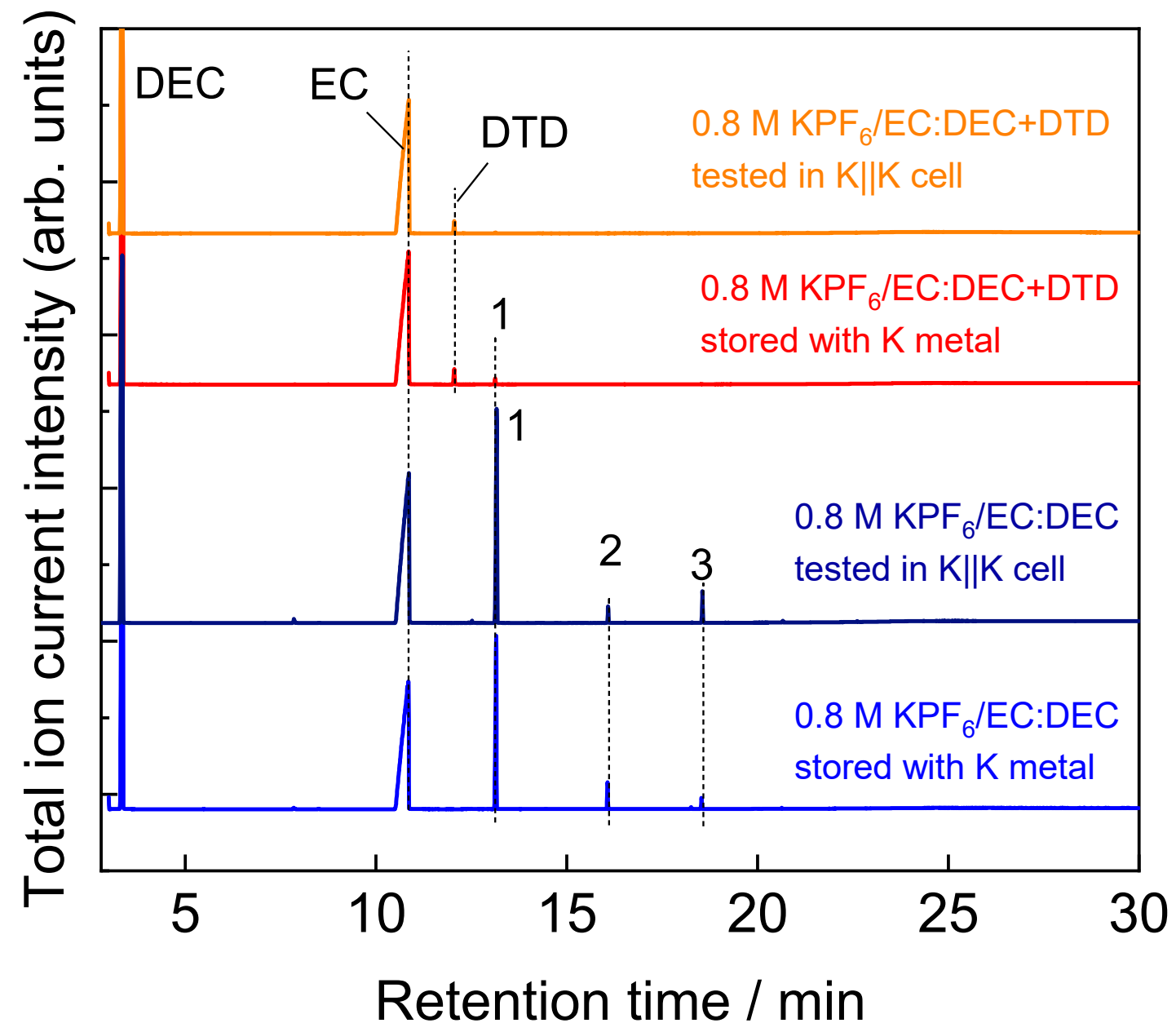

Figure S26. TIC chromatogram of $0.8 \mathrm{M} \mathrm{KPF}_{6} / \mathrm{EC}: \mathrm{DEC}$ and $0.8 \mathrm{M} \mathrm{KPF}_{6} / \mathrm{EC}: \mathrm{DEC}$ +1 wt\% DTD tested in $\mathrm{K}|| \mathrm{K}$ cells after two plating-stripping cycles

\section{Reference:}

1. D. M. Seo, S. Reininger, M. Kutcher, K. Redmond, W. B. Euler and B. L. Lucht, J. Phys. Chem. C, 2015, 119, 14038-14046. 